\title{
Chapter 8 \\ The Economy of Laetanian Wine: \\ A Conceptual Framework to Analyse an Intensive/Specialized Winegrowing \\ Production System and Trade (First \\ Century BC to Third Century AD)
}

\author{
Antoni Martín i Oliveras and Víctor Revilla Calvo
}

\begin{abstract}
The Roman economy has been defined as an agrarian regime, where wheat was mainly cultivated combined with livestock farming and intensive cash crops such as wine and olive oil. Possibilities for economic growth in a winegrowing area such as the Laetanian region in Hispania Citerior depended upon changes in agrarian productivity but were subject to agro-ecological and agroeconomic endowments that could affect the settlement patterns, the fluctuations in population, the forms of production related to the vineyard crop capacities, the spread of new techniques of cultivation and processing and the adoption of new technological advances. The combination of these factors explains how comparative advantages arose from other winegrowing territories, achieved through intensification and specialization processes that generated an increase of winemaking production surplus capable of being traded in different overseas markets.
\end{abstract}

Keywords Ancient viticulture - Laetanian Roman wine - Conceptual framework · Economic models $\cdot$ Intensive/specialised winegrowing production processes

\subsection{Introduction}

Hispaniarum Laeetana copia nobilitantur, elegantia vero Tarraconensia atque Lauronensia et Baliarica ex insulis conferuntur Italiae primis. ${ }^{1}$ - Gaius Plinius Secundus, Naturalis Historia XIV, 71

\footnotetext{
1 "Among the Hispanian (wines), the Laietanian (wine) is famous for its large productivity; beside the Tarraconensian (wine), the Lauronensian (wine) and the Balearian (wine) from the islands, (these ones) gather a certain elegance comparable to the best Italian (wines)" (authors'

A. Martín i Oliveras $(\bowtie) \cdot$ V. R. Calvo

Universitat de Barcelona/CEIPAC-Centre for the Study of Provincial Interdependence in

Classical Antiquity, Barcelona, Spain

e-mail: amartinioliveras@ub.edu; vrevillac@ub.edu
} 
Ancient Roman viticulture has multiple fields of knowledge and expertise with enormous possibilities for research. Most studies dedicated to the development of viticulture in Hispania during Antiquity have in common the use of archaeological information and written sources as a complementary support to confirm the absolute chronology of a settlement, a socioeconomic phenomenon or an exact location of a winegrowing production or a pottery activity in a specific territory (Revilla 1995).

This research builds on previous work in which the theoretical and epistemological framework of study was established of the different variables, factors and endogenous and exogenous agents involved in every stage of the production, distribution, trade and consumption of wine in the ancient Laetanian region between the first century BC and third century AD (Martín i Oliveras 2015b). The intensive viticulture practised during the Roman period in this area situated in the centre of Catalan Coastal Depression was a widespread phenomenon with huge economic implications on the organization of this territory and the local communities.

The main aim of this study is to establish a specific conceptual framework where this phenomenon was developed, selecting the economic models susceptible to be applied and identifying the necessary variables, parameters and constraining factors to take into account to analyse its socioeconomic structure and evolution over the time. This first approach intends to evaluate the relations that could be generated between the development of viticulture and a set of complementary activities between the end of the Republic and the Early Roman Empire in this winegrowing area. In particular, it seeks to explore the impact of certain organizational forms, articulated by rational strategies, large investments in technology, resources and economic intensification processes, which involve labour needs and a precise organization of the global structure of settlement. This impact can be assessed from factors such as rural and urban habitat distribution and density, the calculation of labour needs also in agriculture and handicrafts, both fixed and variable, and its influence on living standards. These factors may be related to others more difficult to evaluate, such as the possible population growth, population mobility or the possibilities of enrichment and social promotion of certain groups related to the wine's economy such as the freedmen (Scheidel 2004).

Further specialized studies must be focused on specific geospatial and geoeconomic analysis, which supposes the identification of the settlement patterns, the organization of the rural habitat, the forms of production and management related to the crop capacities to obtain optimal yields for generating surpluses in a context of a growing population. The utilization of quantitative methods such as mathematics, statistics and linear programming models will allow us to interpret and make predictions, regressions and reconstructions of the evolution of the Laetanian wine economy, understood as a situation that includes all the aspects needed to produce wines of various qualities along with a group of complementary activities related to the production, elaboration, distribution, trade and consumption.

translation). 
Thus, this chapter only attempts to make a first theoretical approach to this specific conceptual framework and its influence on the configuration of this ancient winegrowing socioeconomic system, analysing the possibilities of implementation with a scanty available dataset where estimations will play a decisive role. ${ }^{2}$

\subsection{The Territorial Scope}

The Laetanian region is an ill-defined area in historical terms, organized around some urban centres as, Blanda or Blandae, the municipia of Iluro, Baetulo and the colonia of Barcino on the coast and, among others, the Flavian municipium of Egara, the secondary settlement of Arrago and the thermal station and possible Augustan or Flavian municipium of Aquae Calidae (Caldes de Montbui) inland. The extension and limits of these cities' territories have not been precisely defined with the exception of the ager Barcinonensis, the constitution and legal status of which must have had an effect on the urban centres that were there before (Palet 1997; Palet et al. 2009, 2011, 2012). Otherwise, the process of urbanization and legal promotion of the interior territories seems to assume particular forms, with the constitution of civitas sine urbe, and culminates in the Flavian era. This evolution has been related to the development of new patterns of exploitation and agricultural occupation (Oller 2015).

The Laetanian territory also comprised the extensive plain situated between the Baetulo River (Besós) and the mouth of Rubricatum River (Llobregat), located on the southwest side of the Montjuiic promontory. The first foothills of the Garraf Massif would have risen from this point. Away from the coast, the colony's ager would have included the lower course of the Llobregat River as far as Ad fines (Martorell) and the lower course of the Besós River to where it joined the Ripoll River and the Congost-Mogent basin, spreading across the great Vallès plain as far as the Catalan Pre-Coastal Range. Attending the special features of the Laeetana regio, as regards its particular geospatial configuration, geoeconomic characteristics and historical evolution over time, we distinguish the following four specific research areas of study:

- Study Area 1: Barcelona Hinterland Plain - Ager Barcinonensis (Fig. 8.1)

- Study Area 2: Central Coast - Territoria of Baetulo, Iluro and Blandae

- Study Area 3: Lower Llobregat - Rubricatum estuary

- Study Area 4: Vallesian Plain - Territoria of Arraona, Egara and Aquae Calidae.

\footnotetext{
${ }^{2}$ Estimations are subject of debate among some scholars but have been accepted by most economic historians due to the scarcity of the archaeological data and the absence of more reliable information (De Sena 2005, 2, note 7).
} 

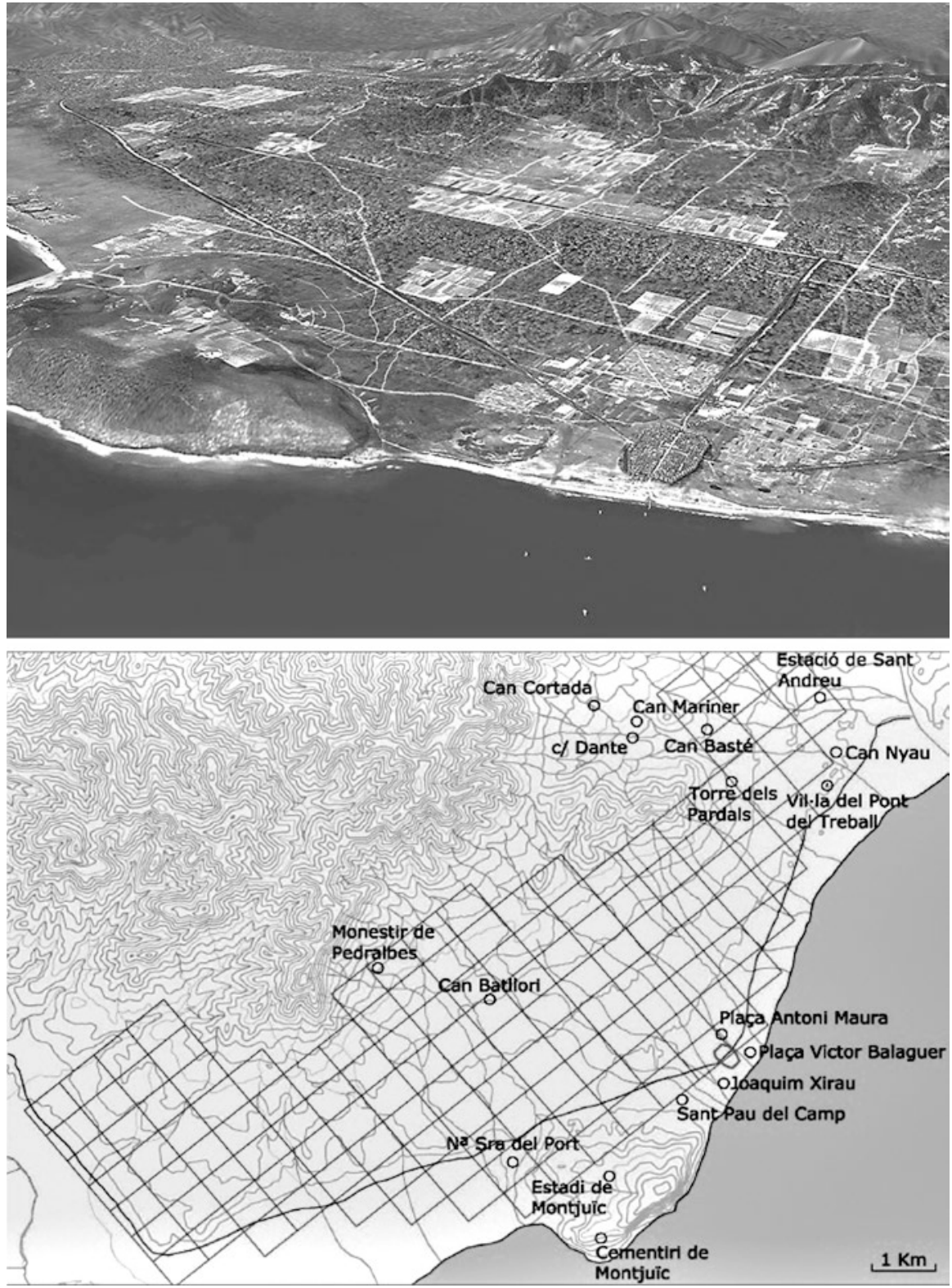

Fig. 8.1 (a) General view of Study Area 1: Barcino Roman colony hinterland plain in the third century CE - from Barcino3D (https://bit.ly/2Kpo4J8); (b) Ager Barcinonensis centuriatio proposal and main Roman villae attested from Palet et al. (2012) 


\subsection{Working Hypothesis}

The amphoric studies carried out in recent decades and the suggestions put forward regarding how to interpret them make it possible to propose an evolutionary sequence of viticulture in this territory during the Roman period from both the perspective of production and trade.

We start with the premise that there are five main chronocultural phases of development, which we consider to correspond to the configuration of different agricultural and artisan production systems (Miró 1988; Martín i Oliveras 2015b; Martín i Oliveras et al. 2017):

- Phase 1. Origins (1/3 2nd c. BC-1/2 1st c. BC): First productions of Citerior amphoric containers imitating forms as Greco-Italic, Dressel 1A, 1B and 1C.

- Phase 2. Expansion ( $1 / 2$ 1st c. BC-middle decades of 1 st c. AD): The appearance of the first widely manufactured amphorae forms: Tarraconense 1/Laietana 1 and Pascual 1, the latter being the first Tarraconense amphora intended for large scale trade. Appearance of first imitations of the Dressel 2-3 italic form.

- Phase 3. Reorientation (middle decades of 1 st c. AD - end of 1st c. AD): Characterized by large-scale production of Dressel 2-3 Tarraconense amphorae form and maybe in dolia (big pottery jars) for the massive export of wine, both individually packaged and in bulk, mainly destined for the Italic Peninsula and the city of Rome itself.

- Phase 4. Peak (early 2nd c. AD-mid 3rd c. AD): Period when the production structures were transformed, probably connected to the transport of wine in bulk in other types of containers such as cupae (wooden barrels) for export and culleii (wineskins) for regional trade, possibly as a consequence of having to reduce costs when supplying heavily-used, strongly competitive markets.

- Phase 5. Decline ( $1 / 23 r d$ c. AD-early 5th c. AD): Crisis and the end of viticulture for export. The phenomenon could be due to the appearance of new producers with much lower costs, which would imply a change in market orientation. The viticultural centres were restructured for supplying only the internal demand for wine and carry out other agrarian activities or were gradually abandoned.

\subsection{Operative Hypothesis}

The intensive viticulture practised during the Roman period in the ancient Laetanian region was a widespread phenomenon with huge socioeconomic implications between the first century BCE and third century CE. Outstanding questions and key structural features suggest important conjunctural changes in the land use increase, the crop regimes, the landowner-tenancy relationships, the population fluctuations, the balance between production and consumption, the investment needs, the implantation of the "villa system" and its evolution as a cash-crop market-oriented surplus production and the prevalence of wine pressing and pottery facilities. This phenomenon can be only explained by an intensification process and the application of an 
agency-oriented winegrowing specialization production system related to a profit mentality that exploited a comparative advantage arose in productivity, a pulled force of product demand and the accessibility of larger distributed markets resulting from the reduction of production and transaction costs (Van Minnen 1998; BadíaMiró and Tello 2013).

\subsection{Conceptual Framework}

Every agrarian activity is determined by environmental conditions composed by multiple variables, factors, endogenous and exogenous agents involved in every stage of the production, distribution, trade and consumption of a good or product. The ancient viticulture production process and trade was not an exception. Our conceptual framework (Fig. 8.2) analyses the relationships among the agroecological and agroeconomic endowments such as paleoclimatic conditions, physical environment, landscape typology, settlement patterns, land use, optimal yields, tax control and other geographical, demographic, economic (price policies and markets), technological (new methods and mechanization), institutional (taxes and fiscality) and sociocultural (tradition and religion) driving forces that could influence and model the evolution of this complex system over time.

\subsection{Agroecological and Agro-economic Endowments}

Agroecological endowments are the combination of constraints that conditioned vineyard crops and the winegrowing production systems under which they are grown. It includes the resilience strategies harnessing ecosystem functions to the

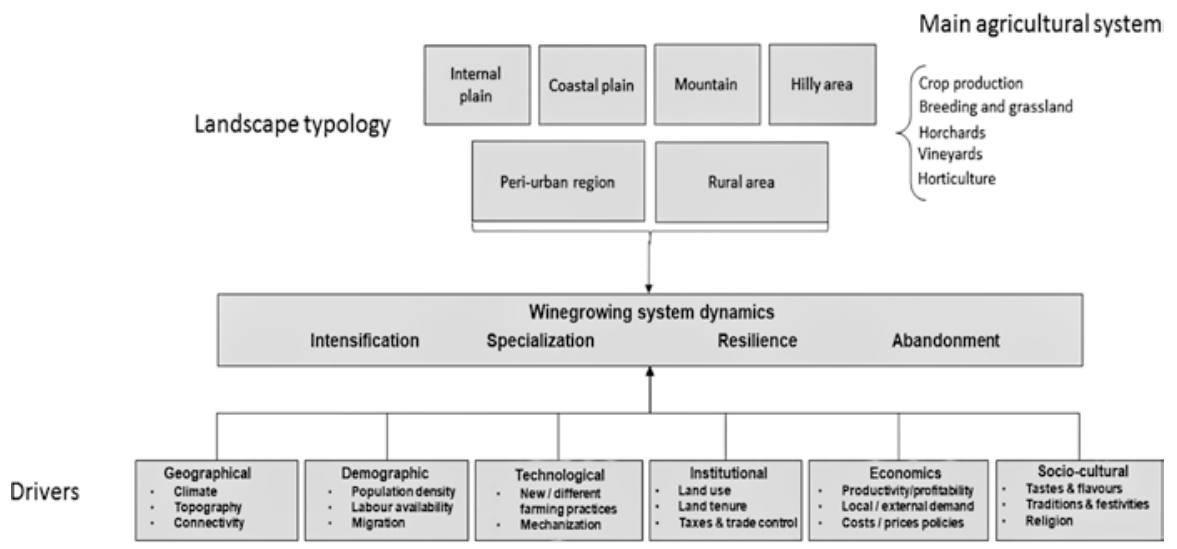

Fig. 8.2 Conceptual framework for land and farming system dynamics. Relationships among driving variables, processes and ecosystem properties. (Based on Debolini et al. 2016, Fig. 2) 
maximum possible extent, to improve the existing land-use situation and winemaking facilities, either through increasing or diminishing the means of production in order to sustainably reconcile social, economic and environmental challenges.

Agro-economic endowments are the combination of constraints that conditioned productivity performance in a territorial or farming plot scale. It supposes the analysis of the economic factors which shaped the winemaking production function on a supply chain. It also means giving economic values to the initial investment for starting the activity and for all the factors of production needed (land, labour, capital, technology, processes etc.), to determine the profitability of winegrowing production and trade.

\subsubsection{Palaeoclimatic Conditions}

Specific macroclimate data as experienced by different regions of the Western Roman Empire and robustly documented by different independent palaeoclimatic proxy data sets testify a favourable and exceptionally stable climatic situation from $100 \mathrm{BC}$ to $200 \mathrm{AD}$ with a prolonged period of warming and wet conditions that favoured the rise of agrarian production yields. It is known as The Roman Warm Period or Roman Climate Optimum (McCormick et al. 2012). All agricultural activity is dependent upon and interconnected to climate and weather conditions; grapes are no exception. Wine composition and optimal productivity is largely dependent on mesoclimatic conditions of a territory and microclimatic environment conditions of a small restricted space such as a vineyard or a row of vines. As such, any shift in climate and weather patterns is bound to affect grapes and the subsequent production of wine. This is important because optimal wine production occurs only within very narrow climate ranges. While studies have indicated that initial climate changes even could have been beneficial for some Roman winegrowing regions in the short run, undoubtedly excessive climate changes were disastrous in the long run.

\subsubsection{Physical Environment}

The physical environment comprises the space where the winegrowing activity is embedded in and also the connectivity and transport infrastructure that are necessary for the efficient operational flow of the production and trade system, such as paths, roads, rivers, streams, ports, etc. Such a physical environment appears as a major external determinant of the movement of goods by terrestrial vehicles and vessels. It thus can become decisive for the success or the shortcoming of the production and distribution system. This follows the consideration of space as a barrier for the notion and the physics of flow. The physical environment plays a more sophisticated role, since it represents the entire pressure that is exerted by space on the supply chain, positively and critically. This happens particularly in those 
territories that are characterized by scarcity of access such as port hinterlands, or core urban areas that are problematic for distribution or delivery of goods. The agents of production and distribution have to arrange themselves with their physical environment conditions over the time.

\subsubsection{Viticulture Supply Chain}

A supply chain is a system of resources and processes involved in produce and trade of a good or service from a supplier to a customer. The viticulture supply chain involves both the production process and trade activities from its inception to its delivery to the end customer or consumer. The production function is the global system that characterizes a productive activity. The factors of production constitute the inputs of the economic system. A specific technology specifically combines these inputs - raw materials, labour, machinery, tools, facilities, etc. The outputs are the finished products, the goods or services resulting from the productive activity (Martín i Oliveras 2015a). In any type of socioeconomic organization, the production of goods and services may be in the hands of the state or in the hands of private producers. The Roman wine production process is not alien to all these factors, conditions and microeconomic variables and has also its particular production function with its own inputs intervening in the different stages of the productive chain.

\subsubsection{Yield Quantification}

Its calculation is fundamental for the study of agricultural production processes, so we will try to adapt it both to the vineyard crop and to the processes of transformation, production and exploitation, in the different stages of the viticulture supply chain (Amouretti and Brun 1993). The analysis of viticultural activities can be approached in several ways according to different parameters of study.

\subsubsection{Vineyard Yields}

Vineyard yields calculate both the yield of the crop itself and the yield from the harvest. To estimate the global vineyards yields we must take into account the following factors:

1. Yield per strain. This refers to the productive capacity of the plant, in order to obtain data on absolute yields and means of productivity of grapes from maximum to minimum. Factors related to both the configuration of the vineyard and the cultivated grape variety, the planting frame and the number of vines/hectare (vitis/iugera), the pruning and loading of buds, the number of hectares/iugera 
cultivated, etc. Once the productive capacity of the plant and the variety of grapes chosen are fixed according to the geomorphological characteristics of the territory under study and the soil characteristics of the land to be cultivated, we will be able to analyse the different parameters and intervening factors, in order to obtain a whole series of values that we can compare with productivity data from the written sources themselves and statistical data of yields from modern and contemporary periods, basically from nineteenth and twentieth centuries.

2. Harvesting yield. Refers to grape collection prior to pressing. The data set and factors to be analysed are of different nature and origin. The most important are the spatial configuration of the vineyards, which can facilitate or hinder the manual grapes collecting of the clusters. This process is conditioned by the harvest time available, which can last from 15 to 30 days depending on the staff's picking expertise and the maturation time necessary for the cultivated grape variety.

3. Winery yields. This calculates the yields from the processes of treading and pressing the grapes, its transformation into must and then into wine, as the maximum productive capacity of the facilities with regard to the processing machinery and the capacity needs of the collecting, ageing, and storing structures.

4. Productivity of the processing machinery. Once we know the technical, mechanical and operational constraints of the Roman beam presses, we can analyse the different parameters and intervening factors that allow us to make an assessment of the productive performance of a winery installation in terms of productive capacity (Martín i Oliveras and Bayés 2009; Martín i Oliveras 2011-2012, 2012, $2015 \mathrm{a}, \mathrm{b})$. The productive capacity measures the ratio of the volume of grapes processed and the volume of must obtained, depending on the time used, counted in hours or days, taking into account the vindemia period related to the characteristics of the grape varieties to be processed. All these factors are connected to each other and influence in the final result, so we will have to calculate the yields in absolute values of maximum productivity in order to get an idea of the real and total capacity, both for the processing and pressing machinery as for the necessary collection and storage structures (lacus, dolia, cupae, etc.; Tchernia 2013). We can also compare the results with the absolute data of productivity and capacity of the installations coming from the written sources, especially from Cato (Cat. Agri.11) and Pliny the Elder (Plin. N.H.XVIII, 317), previously studied by modern scholars, with historical data from modern vintages and with data from experimental archaeology - currently we only have those from the Mas de Tourelles experience (Brun 2004; Tchernia \& Brun 1999). Subsequently, we can extrapolate them to the extent of the vineyard fields to give us an idea of the amount of must and wine that a "typical" installation, with certain characteristics established according to the different typologies of Roman wineries documented in the area, can process, establishing models and systems of production. Their analysis can also inform us about the settlement patterns, the size of properties or fundus and the organization and tax control of the vine-growing and winemaking production in the former territory object of study. 
Table 8.1 Behaviour of the total fixed cost (TFC), total variable cost (TVC) and total cost (TC) of each of the units produced in estimate economic calculation values

\begin{tabular}{l|l|l|l}
\hline Quantities produced & Total fixed cost (TFC) & Total variable cost (TVC) & Total cost (TC) \\
\hline 0 & 2000 & 0 & 2000 \\
\hline 1 & 2000 & 800 & 2800 \\
\hline 2 & 2000 & 1360 & 3360 \\
\hline 3 & 2000 & 1680 & 3680 \\
\hline 4 & 2000 & 1910 & 3910 \\
\hline 5 & 2000 & 2150 & 4150 \\
\hline 6 & 2000 & 2550 & 4550 \\
\hline$\ldots$ & 2000 & 3210 & 5210 \\
\hline 22 & $\ldots$ & $\ldots$ & $\ldots$ \\
\hline & 2000 & 9610 & 11,610 \\
\hline
\end{tabular}

\subsubsection{Cost Quantification}

The production of a particular good or service involves the use of a number of factors that have a quantifiable economic value, the costs. The cost structure of an economic activity is considered as a diagram of consecutive allocation of direct costs (raw materials, labour power and energy) and indirect costs (maintenance costs of tools, infrastructure and facilities and administrative, commercial and financial expenses) (Maza and González 1992). The calculation of production costs of a good or service is complex since it is necessary to take into account all the costs structure and the proportional part of the capital investment.

In order to calculate the productive and commercial costs of a wine amphora, the first thing we have to do is to try to obtain a scale of ancient real prices situated in the chronological context that we want to study. That allows us to make a calculation, as close as possible, to the real productive costs in a fixed-value Roman monetary unit, such as the sestertius (HS; Duncan-Jones 1974). ${ }^{3}$ However, in order to understand the general theoretical framework of costs, we will randomly develop an example of production or service provision $\mathrm{X}$, which can show us the behaviour of the variable costs and total costs of each one good or service produced in units, tens, hundreds or thousands values (Table 8.1; Jones 2014). ${ }^{4}$

The average cost per unit: The average cost (AC) is the total cost (TC) divided by the quantity $(\mathrm{Q})$ of the units produced. Although the total costs are very important, the average costs per unit are even more important for the short-term analysis

\footnotetext{
${ }^{3}$ Quantitative studies have been developed related to the calculation of costs and yields of productive activities and price scales of goods and services in different places of the Roman Empire and chronological periods (Temin 2014, 2017). See also data sets from the written sources and other preserved documentation: Mensa Ponderaria and prices lists of Pompeii (first century AD), Edict of Maximum Prices of Diocletian (301 AD), etc.

${ }^{4}$ The units of value employed in this theoretical example are imaginary and only have a quantitative numeral value expressed in units, tens, hundreds or thousands of units to facilitate economic calculation.
} 
of the production centre (exploitation), since by comparing them with the price of the product or with the average income, we will know when a profit is made. The average costs per unit are essential for the evaluation of inventories in matters related to the "design" of the product. These concepts also play an important role in the introduction of a new product in the market. In modern microeconomics, the decisions to buy or not to buy a product and the decision of reject or accept a new production line depend on the available information on the average cost per unit. Other short-term unit costs are usually calculated to complement the decisions, such as:

- Average fixed cost $(\mathrm{AFC})=$ fixed cost $(\mathrm{FC}) /$ quantity $(\mathrm{Q})$ of units produced

- Average variable cost $(\mathrm{AVC})=$ variable cost $(\mathrm{VC}) /$ quantity $(\mathrm{Q})$ of units prod

- Marginal cost $(\mathrm{MC})=$ cost of each additional unit, defined as the change that affects the total cost (TC), when one more unit is produced:

$$
\mathrm{MC}=\frac{\text { Changein TC }}{\text { ChangeinQ }}
$$

where:

Change in $\mathrm{TC}=\mathrm{TC} 2-\mathrm{TC} 1$

Change in $\mathrm{Q}=\mathrm{Q} 2-\mathrm{Q} 1$

It is calculated by subtracting from the total cost (column 4 in Table 8.1) of row unit, $\mathrm{n}$, the total cost of row unit, $\mathrm{n}-1$; it can also be obtained from the variable cost in column 3 , because variable costs increase in exactly the same way.

The average cost (AC) and the marginal cost (MC) are known as short-term costs, because these act during the period of decision-making, in which some costs are fixed and others are variables. In this example, if the cost of producing 5 units is 20,750 units (where $48.2 \%$ are fixed costs and the remaining $51.8 \%$ are variable costs), and the Average Cost (AC) of production is 4150. If the centre produces one additional unit ( 6 units), the average costs (AC) are reduced to 3790, and by producing 7 units the average cost (AC) continues to decline but when there are 8 again begins to increase due to the law of diminishing returns and due to the increasing number of units for a fixed capital investment. These results are shown in the marginal cost (MC) column 5, in which it is observed as this one decreases to the fourth unit and from here again begins to increase (Table 8.2).

The marginal cost must always be lower than the average cost, but the more units are produced, this will be closer to the average cost, and to justify the production of more units when the marginal cost is above the medium cost, the selling price should be equal to the marginal cost of the last unit produced, so that the activity does not incur in losses when producing this last unit. Table 8.2 shows that the progression of unitary costs is not constant; this is initially decreasing, and then goes to constant progression, to then increases again, generating three moments.

The combination of available fixed resources with small amounts of variable resources will not achieve the full potential efficiency of the exploitation, which 
Table 8.2 Behaviour of average fixed costs (AFC), average variable cost (AVC), average total cost (ACT) and marginal cost (MC) of each of the units produced in estimate economic calculation values (in thousands)

\begin{tabular}{l|l|l|l|l}
\hline $\begin{array}{l}\text { Quantities } \\
\text { produced }\end{array}$ & $\begin{array}{l}\text { Average fixed cost } \\
\text { (TFC/Q) }\end{array}$ & $\begin{array}{l}\text { Average variable cost } \\
\text { (TVC/Q) }\end{array}$ & $\begin{array}{l}\text { Average total cost } \\
\text { (TC/Q) }\end{array}$ & $\begin{array}{l}\text { Marginal cost } \\
\text { (MC) }\end{array}$ \\
\hline 0 & - & - & - & - \\
\hline 1 & 10.00 & 4.00 & 14.00 & 4.00 \\
\hline 2 & 5.00 & 3.40 & 8.40 & 2.80 \\
\hline 3 & 3.33 & 2.80 & 6.13 & 1.60 \\
\hline 4 & 2.50 & 2.39 & 4.89 & 1.15 \\
\hline 5 & 2.00 & 2.15 & 4.15 & 1.20 \\
\hline 6 & 1.67 & 2.12 & 3.79 & 2.00 \\
\hline 7 & 1.43 & 2.29 & 3.72 & 3.30 \\
\hline 8 & 1.25 & 2.57 & 3.82 & 4.50 \\
\hline 9 & 1.11 & 2.92 & 4.03 & 5.75 \\
\hline 10 & 1.00 & 3.40 & 4.40 & 7.75 \\
\hline
\end{tabular}

supposes high unitary costs for the first products. As the scale of units produced increases, the proportions of the combination of fixed resources with variable resources allows better overall returns, reducing these costs in proportion to the units produced. Production continues to rise until the fixed resources do no longer support the production of additional units under equal conditions so that they will be processed at higher proportions cost.

See the following graphs, which represent, on the one hand, the behaviour of the total fixed cost (TFC), the total variable cost (TVC) and the total cost (TC) (Fig. 8.3I) and, on the other hand, the behaviour of the average variable cost $(\mathrm{AVC}=\mathrm{TVC} / \mathrm{Q})$ and the marginal cost $(\mathrm{MC})($ Fig. 8.3L).

The total fixed costs (TFC) are by definition equal and independent of the level of production, and the average fixed cost ( $\mathrm{AFC}=\mathrm{TFC} / \mathrm{Q})$ decreases as production increases and is represented by a continuously lowering curve. When the production increases by adding variable resources, because the total variable cost (TVC/Q) reflects the law of diminishing returns, we can first obtain increasing returns, but in the end it would yield diminishing returns; then the average variable cost (TVC /Q) decreases at the beginning, and it reaches a minimum and returns to increase, so the graph is U-shaped. The marginal cost curve (MC) reaches its level lower in four units, below cost mean variable (TVC/Q) or the average total cost (TC/Q) and cuts the mean the total variable cost curves (TVC/ Q) and the average total cost (TC/Q), respectively, low points, because while the cost (MC) is below the average total cost (TC/Q), the average presses down, and when it is above, the average presses upwards (Fig. 8.3K).

The long-term production costs: As a result of a successful operation, a winery can modify its installed production capacity to expand it, or in case of different results expected, in the long run it could also reduce their size. Either decision seeks to obtain the lowest average total cost (ATC) of possible production. The reduction 

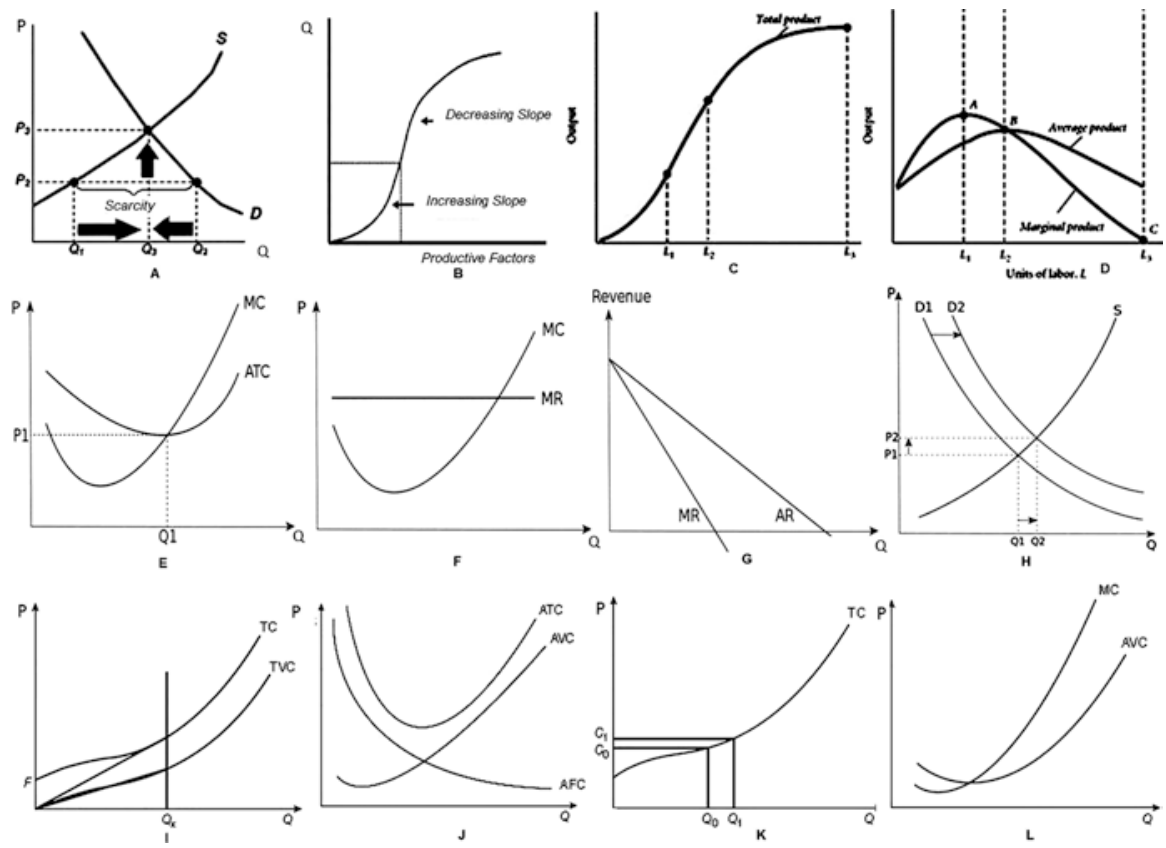

Fig. 8.3 (A) Principle of economic scarcity; (B) production function curve; (C) and (D) comparative charts of law of diminishing returns. (After Maza and González 1992); (E) economic efficiency graph; (F) curves of marginal cost (MC), in relation to marginal revenue (MR) in situation of perfect competition; (G) marginal revenue (MR) curve with respect to average revenue (AR) (H) supply (S) and demand (D) curves; (I) cost curves: total cost (TC) and total variable cost (TVC); (J) average total cost (ATC), average variable cost (AVC) and average fixed cost (AFC) curves; (K) the marginal cost concept; (L) marginal cost (MC) and average variable cost curves. (After Jones 2014)

in the price of resources and technological progress displace cost curves down. Similarly, the increase in the price of resources shifts it up (Fig. 8.3J; Vilcalpoma 1995; Jones 2014).

\subsubsection{Economies of Scale}

The decision to expand the winery seeks to achieve economies of scale or serial production. When the size of the centre increases, factors such as specialization of labour, better utilization of staff, efficient use of capital and technical resources, the allocation of indirect costs and other costs arising from the expansion of the producing centre in a number of units, contributes to reduce the unit costs for the producer, who can expand its scale of operation. It is, therefore, the set of circumstances that allow reducing the average cost of production as the total product increases. They are also defined as gains in production and the costs resulting from the increase in 
the size of the producing centre, which implies an improvement in the buying prices of the inputs or factors of production and a most efficient use of them. The improvements in economies of scale can be internal, due to the indivisibility of the factors of production, or external, due to the expansion of the producing centre as a whole. Economies of scale stimulate mass production and are achieved rapidly when the size of the producing centre increases, which means that the decreasing returns only appear when the scale of production is very high, the total average cost decreases over a wide interval of production. This can lead to the development of monopolies and oligopolies of producers and investors, due to the large initial investments required and the difficulty of obtaining minimum short-term yields and costs, in order to protect themselves against new competitors. For example, when an amphora of noble wine is produced, high fixed costs must be faced to buy the land, plant the vines, build the torcularium, the cella vinaria and other facilities, but when this entire infrastructure is already operating at full capacity, the cost of filling an amphora of wine is more or less the same. Thus, if these infrastructure costs hypothetically 20,000 units of investment and the production of each wine amphora costs hypothetically 500 units, the "real" unitary cost is 5 units producing 100 wine amphorae, 2.5 units for 200 wine amphorae and 1 unit for 500 wine amphorae.

\subsection{Demographic Dynamics, Workforce Availability and Labour Division}

Demographic studies of ancient societies have increased over the last years, trying to recognize the internal organization of the population's evolution and to identify possible settlement patterns related to resources management, urban development and agrarian exploitation of the territory. These studies allow us to revise basic concepts such as the relationship between the urban and rural world, as regards the urbanism development related to the implementation of an intensive agrarian production system and the different administrative status, sizes and ranges of ancient Roman cities (Morley 1996; for Hispania: Carreras 1996, 2014).

Quantitative and qualitative analyses of territories have been favoured by a better knowledge of the urban perimeters and the settlement patterns of rural distribution; either from the contribution of urban archaeology, field-surveys, and cadastral studies (Lo Cascio 1994, 1999; Scheidel 2002, 2007a, b; Fentress 2009; Launaro 2011). Therefore, the most important interrelations to take into account for the analysis of demographic inference and population dynamics is the total size of the population, its distribution - urban or rural - and its internal configuration trends, such as gender, age, social status, etc., for every chronological period in the study area. This serves to calculate, on one hand, the needs of foodstuffs in terms of maintenance and self-consumption and, on the other hand, the workforce availability necessary to make the different activities that allows the wine intensive system of production, distribution and trade works. In this same sense, some scholars attempted to convert 
Table 8.3 Typology of rural Roman settlements and estimation of inhabitants according to Carreras (2014), after Perkins (1999)

\begin{tabular}{l|l|l}
\hline Type & Size & Inhabitants \\
\hline Large vicus & $800 \mathrm{~m}^{2}$ & 80 persons \\
\hline Large villa & $500 \mathrm{~m}^{2}$ & 50 persons \\
\hline Small vicus & $400 \mathrm{~m}^{2}$ & 40 persons \\
\hline Small villa & $300 \mathrm{~m}^{2}$ & 30 persons \\
\hline Large farm & $100 \mathrm{~m}^{2}$ & 10 persons \\
\hline Small farm & $60 \mathrm{~m}^{2}$ & 5 persons
\end{tabular}

the results obtained from archaeological excavations and field-surveys into demographic data (Witcher 2005, 2008, 2011). Thus, some analyses achieve to develop ranges of estimated inhabitants by settlement typologies, despite important methodological problems, such as the nature of the samples and the partial data obtained, due to the fact that not the entire territory can be excavated or prospected properly and not all domestic or habitational spaces have been preserved (Table 8.3).

Others studies try to quantify the food supplies necessary to cover the basic diet of resident population in urban and rural settlements with regard to the main crops and other derivate products - wheat, vegetables, wine and olive oil - as well as animal husbandry, to transform them in estimates of units of land necessary to produce it (Garnsey 1979, 1983; Tchernia 1986; Amouretti 1986).

The Roman agronomists such as Cato (Agr.1-11), Varro (R.R 1.4-1.11), and Columella (R.R. 3.3.8-9) also inform us about some environmental aspects, labour requirements and facilities to consider for managing an agricultural holding. These can all help us to calculate the minimal unit of land necessary for self-sufficient maintenance ${ }^{5}$ :

1 worker $=7$ iugera (iug) vineyard

1 worker $=51$ modii $(\mathrm{m})$ wheat $/ 1$ year

1 iug $\times 4 \mathrm{~m}$ seed $\times 3 \mathrm{~m}$ wheat $=12 \mathrm{~m} / 1$ iug

51: $12=4.25$ iug

6.138 iug for wheat and reposition of seed

$6.138 \times 3($ triennial rotation system $)=18.414 \mathrm{iug}$

$18.414+7=25.414 \mathrm{iug} / 1$ worker

The internal quote of wine consumption has been also an important parameter to take into account, so that the balance between intra-regional and extra-regional consumption can determine the performance of the intensive productive wine economy in our study area and the possibility to obtain surpluses for trade and benefits for increasing social position of intervenient agents such as vilici, conductores, mercatores, negotiatores, argentari, naviculari, institores, etc.

\footnotetext{
${ }^{5}$ Calculations made by Martín-Arroyo (2016), for modeling minimum needs of arable land for self-consumption labour maintenance in a standard fundus. According to Roman agronomists data, mainly Columella (R.R. 3.3.8-9).
} 
Endogenous and exogenous factors such as economic success and wealth increment can stimulate population growth, otherwise poor harvests, wars, diseases, plagues, etc. can provoke social conflicts and economic crisis that makes the population decline. In this sense, where it concerns the Laetanian region, historical events such as the Antonine Plague (165-189 CE and the Plague of Cyprian (250 $266 \mathrm{CE}$ ) could have caused widespread labour shortages in agriculture and important casualties in the Roman army that could make conditions change and affect the system.

Regarding workforce availability and labour division we don't dispose of datasets for the Laetanian region in these periods. It means that we should make estimations taking into account the information provided by the written sources and modern rental wage ratios from nineteenth and twentieth centuries. Another way is to develop a general scaling theoretical model to study the relationship between the population and functional diversity of settlements as an indicator of the division of labour (Hanson et al. 2017).

\subsubsection{Settlement Patterns: The Archaeological Dataset}

The progress in archaeological field research has shown itself to be an essential resource for defining the geography of vineyards, since the technological evidence relating to the production and storage of wine or the manufacture of amphorae containers can, in many cases, be located and dated with reasonable accuracy. Archaeology's contribution has also been essential for increasing our knowledge about the rural habitat, settlement patterns and how the territory was occupied and exploited (Revilla et al. 2008-2011). ${ }^{6}$

The establishment of viticulture in the Laetanian region is already confirmed in the final third of the second century BC supposing a progressive transformation of the settlement patterns and the forms of production (Revilla 2004b, 2010b). This development brought with it a need to manufacture specific containers for transport, in the form of imitations of the Dressel 1 and Lamboglia 2 Italic amphorae ("El vi a l'antiguitat" 1987, 1999; Prevosti and Martín i Oliveras 2007; López Mullor and Martín i Menéndez 2008). However, the spread of vineyards geared towards commercialization for overseas markets did not come about until the second half of the first century BC, specifically in the final third of that century. This incipient vinegrowing and winemaking intensification process is confirmed by the foundation chronologies of many pottery workshops and numerous villa-type settlements and other rural centres, equipped with facilities for pressing and storing wine production (Revilla 1995, 2008). All this suggests that these were places given over to specialized, intensive work processes forming part of a production structure organized elsewhere, possibly a nearby villa. Indeed, some buildings were occupied only sea-

\footnotetext{
${ }^{6}$ The bibliography on rural settlement patterns in the Laetanian region is difficult to summarise.
} 
sonally, during certain phases of the agricultural cycle (some examples in Burch et al. 2005 and Revilla 2010a).

Almost ninety agrarian establishments have been identified in Laetanian Region having traces of pressing facilities or spaces for storing liquids, mainly wine. These facilities vary greatly in importance, from modestly-built settlements with a single press to large buildings with four or more presses (Sánchez 1997; Prevosti 2005; Revilla 1998, 2010a; Martín i Oliveras 2009, 2012, 2015b; Palahí and Nolla 20107; Alcubierre et al. 2015, in press $^{8}$; Peña 2010, 2011-2012.

So, we can distinguish three different sizes:

1. Small establishments $400 / 500 \mathrm{~m}^{2}$ with a simple spatial organization formed by one or two spaces compartmented also dedicated to winemaking production with a single press without cella vinaria or with limited storage capacity (5-10 dolia). These facilities often are integrated into small or medium size villa or urban domus and are different from other small buildings or huts dedicated to diverse functions (sheds, tool warehouse, etc.), equally related to the main building unit. The production seems aimed at self-consumption or for local and regional trade.

2. Medium establishments $1000 / 1200 \mathrm{~m}^{2}$ with a wide range of buildings for agrarian activities. Most were used for producing wine and had one or two presses, a collecting lacus and a cella vinaria of between 30 and 50 dolia. These are the most common winegrowing facilities documented in the Laetanian region during the intensification process. The production seems aimed at interregional and interprovincial trade.

3. Large establishments $1500 / 2000 \mathrm{~m}^{2}$ with a complex spatial organization and a basically productive function geared towards winegrowing specialization and long-distance trade. These places would contain all infrastructure needed for making and storing wine on a certain scale. There are several calcatoria for crushing the grapes, some pressing rooms or torcularia with from 4 to 6 presses, various tanks or lacus for collecting the must and different storing spaces set aside of between 100 and 200 dolia called cellae vinariae. Viticulture seems to remain in some of these facilities during the second to fourth centuries AD.

Artisan activities such as pottery workshops, forges and so on; have also been identified in most of these settlements. This type of viticulture geared towards exporting to overseas markets would continue, depending on the area, until the mid or late second or even the early third century AD, when agricultural establishments would see the abandonment or gradually reduction of pressing facilities between the second half of the second and the beginning of the third century AD. In the case of pottery workshops, almost fifty of them have been documented at Laetanian Region and some would disappear between the middle of the first century (Flavian period)

\footnotetext{
${ }^{7}$ Facilities with 4 bean presses were attested in Vallmora (Teià, Maresme, Barcelona), Can Pedrerol de Baix (Castellbisbal, Baix Llobregat, Barcelona) or Els Ametllers (Tossa de Mar, la Selva, Girona) Roman Villa.

${ }^{8}$ Facilities with 5-6 presses were attested in Pont del Treball Digne -La Sagrera- (Barcelona, Barcelonès) Roman Villa.
} 


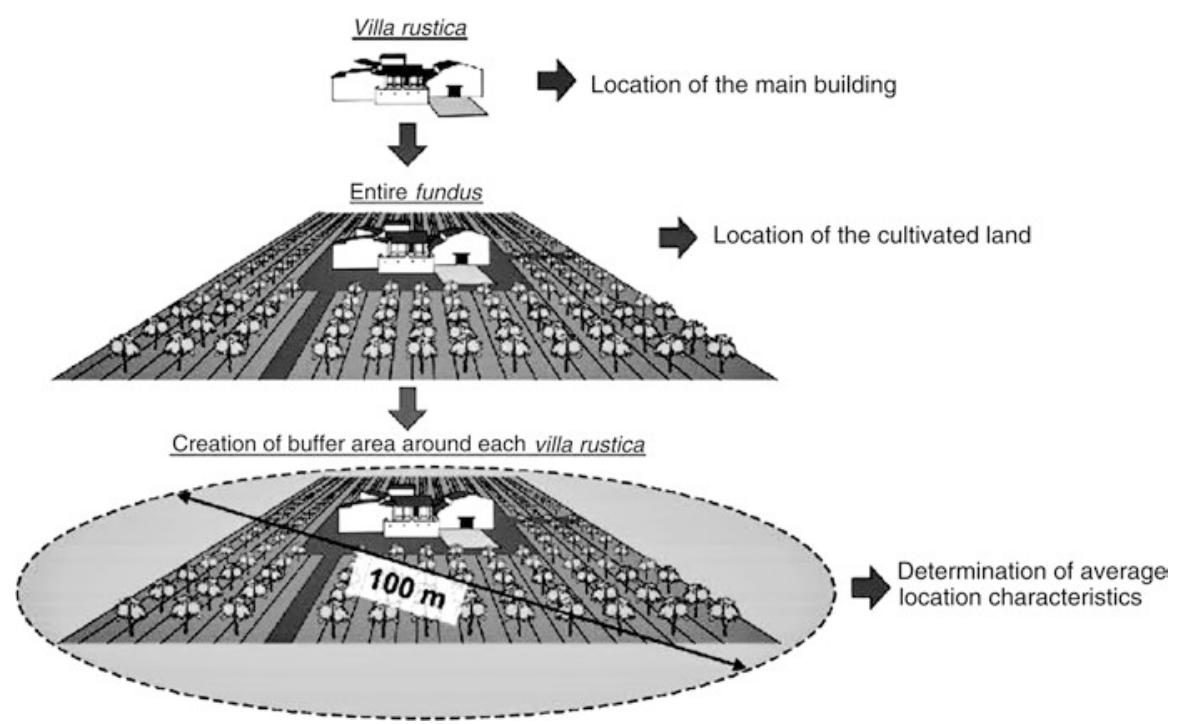

Fig. 8.4 Determination of average location characteristics of the villae rusticae and their surrounding cultivated land using buffer areas. (After Vogel et al. 2016, Fig. 4)

and the start of the second century AD (Antonine period), while others would convert and diversify their production. This ensured their continuity during the second and third centuries AD (Revilla 1995, 1998, 2004a, 2015; Martín i Oliveras et al. 2017; Tremoleda 20089) (Fig. 8.4).

\subsubsection{Land Use, Tenure and Ownership Management}

Land use is the management and modification of natural environment into an anthropised landscape with the development of rural and urban settlements and other open areas such as arable fields, vineyards, pastures, grasslands and managed woods. It necessarily implies the distribution of land resources among the population developing different land ownership and tenure systems.

Land tenure is the legal regime in which land is owned by one or various individuals who hold the property. Land tenure and ownership management can be studied as ancient social traditions according to territoriality and kinship relationships. ${ }^{10}$

\footnotetext{
${ }^{9}$ Where it concerns the management of torcularia and figlinae.

${ }^{10}$ Territoriality refers to the ways in which people create and utilize landscape boundaries (both natural and constructed) to define the extent of their properties. Kinship refers to the web of social relationships that increases the land tenure whether by affinity (marriage) or consanguine links (inheritance).
} 
This makes it possible to study the long-term consequences of change and development in land tenure systems and agricultural productivity.

During the Roman period the distribution of lands in conquered territories such as the Laetanian region was unequal. Some ancient properties and tenure traditions were respected among the inhabitants and ancient Iberian elites not opposed to the Romans. Notwithstanding, the Roman state's need of land for paying veteran soldiers by deductio implies that land tenure changed especially during the first quarter and the end of the second half of the first century BC. It coincides with the end of some war episodes such as Sertorian War (80-72 BC), Triunviral Civil Wars (49-31 BC), Cantabrian and Asturian Wars (29-19 BC) and with the foundations dates of some main cities like Baetulo (ca. 100 BC), Iluro (ca. 80-75 BC) and the colonia of Barcino (ca. 15-13 BC). The new Roman landlords were to keep the yearly income from land exploitation as stable as possible, and solving this economic constraint supposes that in the first stage they took toward managing their own farming states. However, tenancy practices were also a good way to assure a certain economic security.

The term "tenancy" refers to a type of sharecropping arrangement in which a landowner can make full use of the property he may not otherwise be able to develop properly. A "tenant" or nonlandowner will take residency on the fundus and work on the land in exchange for giving a percentage of the profits from the eventual vineyard crop or winegrowing yield. In this case the landowner would extend to the farmer's house-holding food and necessary items on credit to be repaid out of the tenant's share. The landowner could, if he desired, charge the tenant extremely high interest on the advanced pay since there were no lending laws applicable to migrant or tenant workers at the time. This could ultimately result in the tenant owing the landowner more money than his share of the crop at harvest and forcing the farmer to be further indentured to the landowner. This practice was used frequently by landowners after slaves were manumitted (Kehoe 1997 ${ }^{11}$; Kloppenborg 2010 Olesti 2006, 2009; Olesti and Carreras 2012, 2013 ${ }^{13}$ ) (Fig. 8.5).

\subsubsection{Connectivity, Transport Infrastructures and Taxation}

Regional, inter-regional and extra-regional trade was a common feature of the Roman world. A mixture within state control and a free market approach ensured that consumer goods produced in one territory could be exported far and wide. Foodstuffs such as cereals and agrarian processed goods such as wine and olive oil were exported in huge quantities. The Roman Empire included regions which were completely different from one another. Notwithstanding, all of these agrarian

\footnotetext{
${ }^{11}$ Approaches to profit and management in Roman agriculture.

${ }^{12}$ Some examples of vineyard tenancy in Roman times.

${ }^{13}$ Concerns some cases of freedmen's social promotion and landownership's evolution in Laetanian region during the Roman period.
} 


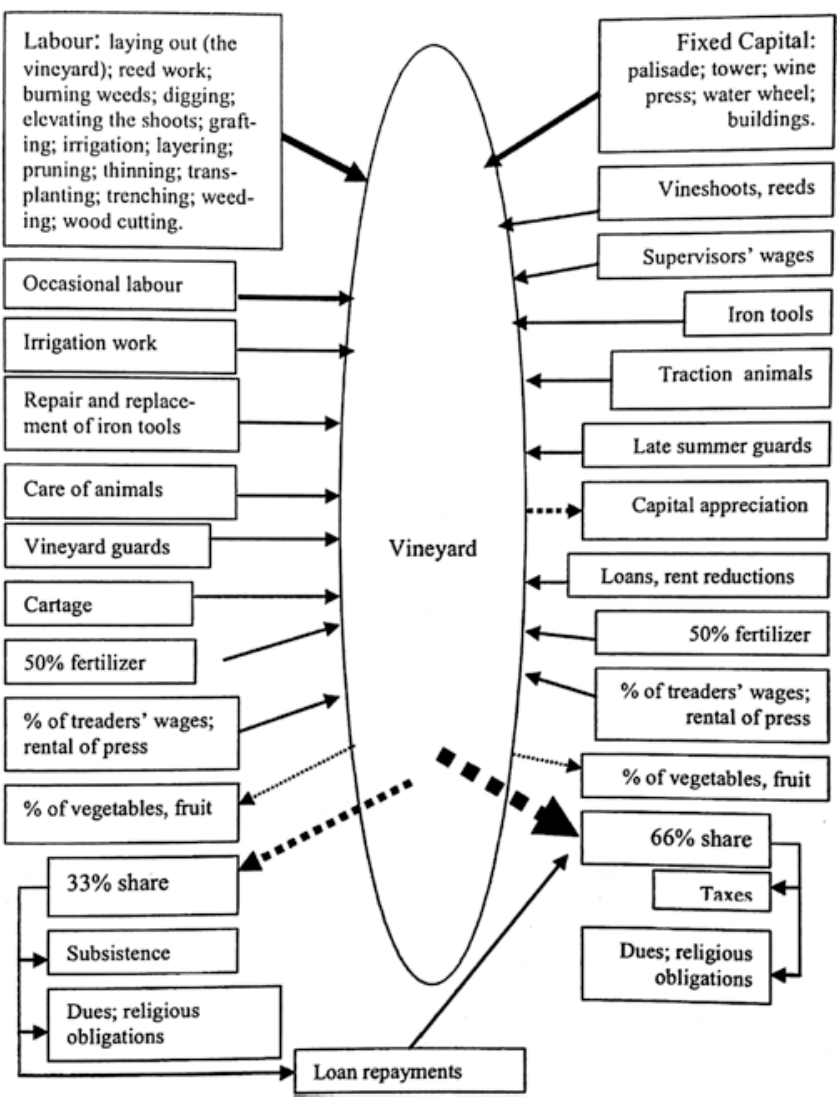

Fig. 8.5 Inputs and outputs of crop-share leased vineyard. (After Kloppenborg 2010, Fig. 6)

regions were linked through a network of trade routes (nautical and terrestrial) that supposes an important mobility of goods and people but integrated in a larger common tax structure. All the inhabitants of these regions pay taxes directly or indirectly to the Roman state. Taxes could be raised in money, earned through regional, inter-regional or extra-regional trade, or in kind, through agrarian production surpluses obtained by the exploitation of land. Public or private investments of capital were also an important factor to take into account. When the state did not spend much money on connectivity infrastructure between the internal production centres, cities and ports, the region had to finance this deficit through the revenues obtained by the internal and the external trade of goods produced and sold.

In the case of Laetanian region, winegrowing intensification/specialisation combined with other related crafts and trade activities could develop recurrent patterns and rhythms in the forms and scale of places, spaces, connectivity and mobility of 
goods and people over time. We will consider the structure and organisation of the physical environment, the settlement patterns, the regional structure and the transport corridors, the relationships between city and countryside and the changes in the labour market within the wider context of demographic, social, and institutional infrastructure, considering issues such as the impact of migration and slavery on the economic opportunities available to the freeborn access to training, apprenticeships, and capital. We also have to consider the potential roles of work's organisation and social relationships related such as chattel slavery, wage labour, patronage and clientelism that could have created important floating population dynamics mainly during the vindemia seasonal periods (Martín i Oliveras et al. forthcoming ${ }^{14}$ ).

\subsection{Economic Models Applied: Agrarian Systems, Population Dynamics, Taxes and Trade Policies}

Most of the recent attempts on quantification of Roman economic activities were made on the wide-scale of the Roman Empire and have adopted a top-down rather than a bottom-up approach (Scheidel and Friesen 2009; Bowman and Wilson 2013). They often pay too little attention to territorial or chronological variation in terms of change in the forms of production, to its diachronic evolution over the time and make no attempt to identify and aggregate individual, local or regional production, as well as consumption and income distribution. On the one hand, they do not take into account the minimum level of subsistence and, on the other hand, they do not calculate the maximum surplus capacity in an intensive and specialized winegrowing production situation such as the case study we have. Here we try to show, from a necessary joint perspective, different economic formal models and demographic analyses systems that could be adopted for explaining this evolution in our different study areas and scenarios of the Laetanian region.

\subsubsection{The "Roman Villa” System}

The "Catonian" villa was originally defined as an autarchic agrarian production system where its main aim was to be self-sufficient in a context of a closed economy, meaning from a theoretical point of view, that no imports are brought in and no exports are sent out. Varro and Columella both dutifully observe that agricultural production and not residential building is the main theme of an agronomical treatise, placing the agricultural activity as the productive system's reason of being, (Wallace-Hadrill 1998). Andrea Carandini went further and presented the "Roman

\footnotetext{
${ }^{14}$ Concerns winegrowing production and demographic dynamics in Laetanian region. Floating population dynamics are still present between some winegrowing regions of Europe and all over the world.
} 
Villa" as a "bisectorial" model where the agrarian productivity and technological autarchy responds to a competitive strategy in a context of a global economy mainly regulated by market constrains (Carandini 1980, 1983, 1989a, b). ${ }^{15}$ Therefore, the main goals are first to cover the own needs in terms of suitability and second to generate surpluses from their agroecosystem borders for sale and trade, in terms of profitability (Gliessman et al. 2006). ${ }^{16}$ It supposes that every agrarian economic unit should produce the required supplies for maintenance of its own inhabitants and the population of a determined territorial scope. Most villae were food-production centres made up from cultivated fields, meadows and forests. Watermills, cowsheds, grain dryers, wine cellars and kilns were other typical farm facilities. Artisan activities such as pottery production and blacksmith workshops related to farming processes have been also documented. Villae produced wool, leather and tallow in addition to food. Hunting, fowling and fishing were also common activities and sources of food protein as well.

Slave-based villae existed in large numbers in Italy, but we can suppose that free peasants and tenant farmers working for villae were the common workforce in other provinces. The Roman institution of slavery in the empire also provided other options and incentives. Many slaves were rewarded for their good services and there were also opportunities to earn money and buy their own freedom. A promising young slave might attend lessons of specialized studies. Thus, the domini could bring up secretaries, accountants, administrators, and tutors for their own use or for renting them out. By the end of the second century $\mathrm{AD}$, up to $80 \%$ of the Roman population were composed by old citizens, freedmen (emancipated slaves) or by their descendants and at the end of the empire most slaves worked in domestic service rather than as labourers on the agrarian properties (Dyson 2003; Johnston 2004; Bowman and Wilson 2013).

The landscape of north-west Hispania Citerior shows a diversity of situations. More fields were used for pasture than for crops because of the need for cattle, sheep and forage. Local people also managed the forest intensely for wood and wild products. Villages and hamlets were denser in the countryside during the Iberian period (fifth-third centuries BC) and tribal areas probably were divided into borough parcels. Each one usually had a settlement at its centre, and sometimes they were located closer to a road, stream or waterway. The Romans enhanced this agrarian system without dramatically altering it. An appropriate water source was the primary site-location factor for a villa. Cisterns for collecting rainwater and deep wells were often build and dug to ensure enough drinking and clean water for the family, labour and livestock. Clean water was also essential for watermills and eventually baths, the Roman indicator of a fully civilized life. The villae were also

\footnotetext{
${ }^{15}$ It supposes the production of fixed assets as a precondition for to the production of exchange goods but also for trading; ultimately both situations involve a regular link with market structures.

${ }^{16} \mathrm{An}$ agroecosystem is the basic unit of study in agro-ecology, and is somewhat arbitrarily defined as a spatially and functionally coherent unit of agricultural activity, and includes the living and non-living components involved in that unit as well as their interactions.
} 
related to a broader Roman economy through a system of primary, secondary and tertiary roads. These were sometimes built or maintained by villa owners or tenants, especially if crossed their lands.

The establishment of intensive viticulture in the Laetanian region is related to the thorough transformations brought about by the Roman conquest. Especially interesting in this sense is the existence of early wine production in the territory close to the indigenous oppida of the central Catalan coast, which survived until the midfirst century BC. This situation is already confirmed in the final third of the second century $\mathrm{BC}$, in connection with a global transformation of the settlement patterns and the production structures probably associated with the displacement of some Italic immigrants (Miret et al. 1991; Revilla 2004b, 2010b).

Roman viticulture spread rapidly close to the change of era and throughout the first half of the first century $\mathrm{AD}$, covering new territories or exploiting more intensively those spaces that were already occupied. The first evidence are placing in the north coastal area situated between the Baetulo flumen (Besós River) and the Arnum flumen (Tordera River), where the villa system had been strongly established since the Augustan period, organized around two municipia, Baetulo and Iluro, and the small oppidum of Blanda or Blandae. These rivers and other minor streams connected the coastal settlements with the inland territory, ensuring access to other agricultural spaces and their resources. It also affected the plain area situated between the Rubricatum (Llobregat River) and Baetulo (Besós River), where the deductio of the colony of Barcino supposes an important territorial reorganization. During the first century AD, increasing economic interests of important gentes from the colony would consolidate their presence in this whole area. This explains the socioeconomic development of Barcino over the first and second centuries AD (Rodà et al. 2005). This specific distribution responds to different ways of exploiting the territory, characterized by a particular architecture defined by a differentiated spatial planning. In general, the technology for winemaking, including several presses along with one or more tanks for collecting the must, is found in buildings close to the residential sector. But they could also be a little further away. Some villae had the agricultural and artisan sectors set apart from the residential area. In some places, however, there is evidence of the simultaneous storage of a cereal production, either for personal use or for trading (Revilla 2011-2012). Some of these establishments had also a pottery workshop where amphorae and other ceramic products were made. So far over 90 figlinae have been identified in the NE of Citerior's province and almost 50 of them are located in the Laetanian region (for figlinae see Tremoleda 2008, 116, Fig. 2 and Martín i Oliveras et al. 2017, 221, map 1; for torcularia see Revilla et al. 2008-2011, 88, Fig. 2 and Martín i Oliveras et al. 2017,222 , map 2). These features suggests that these were places given over to intensive and specialized work processes forming part of a production structure organized from elsewhere, possibly a nearby villa. Indeed, some buildings were occupied only seasonally during certain phases of the agricultural cycle (Burch et al. 2005; Revilla 2010a). ${ }^{17}$

\footnotetext{
${ }^{17}$ With some examples of secondary winemaking productive settlements.
} 
The Roman villae documented in Laetanian region were often settlements with a former occupation in an already intensely farmed landscape. These settlements took the form of large investments and technological improvements enhancing the economic structure which included the transport of raw materials and the transformed goods to distant and large markets. The primary early-Roman modifications were technical and technological improvements, which often meant an intensification of agrarian production and its orientation towards a proto-market economy. One of the major technological innovations was a bigger plough, which could break up the heavier soil. This new plough cut deeper into the soil, and the peasant could regulate its depth. It was usually pulled by two to eight oxen. Other techno-functional innovations on cultivation, tools and machinery for transforming processes were applied in different intensive cash-crops as winegrowing production activities (Martín i Oliveras 2012, 2015a, b). The results of these innovations were the spread of vineyards, the emergence of large estates with great winemaking facilities, population growth and wealth increase with the large-scale surplus of food produced and trade.

\subsubsection{Boserup's Model of Population Growth and Agricultural Intensification}

Archaeological conceptions of agricultural productive intensification during the Roman period related to the abandonment of subsistence model, the rise of an intensive agrarian production, the spread of large-scale trade, the population's growth and the development of social complexity in an open economy context are still an unresolved debate, and there are different explanations for it.

Boserup's model claims that intensification of production refers to an increase in the productive output per unit of land or labour (Boserup 1965). This increase may be achieved in a number of different ways. The variables that held constants are: land, in reference to capacity of food production on a given area by agriculture, hunting, fishing or gathering; labour, in reference to workforce needed for increasing efficiency in yields, craft production and so on; and the capital, necessary for investments and maintenance of transforming facilities and technology (tools and machinery). Alternate temporal parameters as compulsory fallow for grain crops or growing and mature periods for viticulture, are also important factors to take into account in the economic strategies adopted for obtain an optimal amount of productive diversity or specialized intensive production. Boserup's model also defines population pressure as a pushing force driving intensification of agricultural production and, at the same time, as a resilience factor for balancing the change in land, in order to guarantee its sustainability.

On the contrary, the Malthusian proposal defends an agroecosystem collapse (Malthus 1798). Thus, while Malthus saw land and particularly the availability of arable soils as limiting factors in terms of frequency of cropping for the increase in production that eventually would be outstripped by a decontrolled growing popula- 
tion, Boserup turned the double production-population pair around the land and labour use along an adaptable extensive-intensive continuum (Rubin 1972). Other variables such as the technical or technological advantage in cultivation systems, the diversity of crops such as productive strategies, the importance of mobility and the access to resources can contribute to sustain a growing density of population by the intensification of production (Morrison 1994).

The notion of population pressure is also associated with agroecosystem carrying capacity. The calculation of carrying capacity requires the specification of two main concepts related to environmental potential and agro-economic pattern (Dewar 1984). Then, agricultural productive intensity is not only a simple consequence of human-land ratios. Decisions taken by producers to intensify or extensify crops to face contingent conditions or negative factors such as bad harvests by adverse climatology; non-availability of labour due to wars, plagues or diseases; increase of land rents by increase in taxes and prices; fluctuations of internal or external demand, increase or decrease in costs or sales prices; and so on respond rather economic strategies than changes in population size. It does not mean that demographic factors are not important, but they may be affected by other proximate factors and constitute only one aspect of human productive organization. Human populations possess not only size but also structure, so that population size and growth rates will be determined by age-specific fertility and mortality rates. In agestructured populations the distributions of various age groups and the nature of the domestic cycle impinge directly on the organization of labour. Other factors as the social condition either as free citizen, freedman or slave, the administrative situation and relationships between owner and tenant, master and servant, patron and client, will be determinant for an overall analysis of the population dynamics and the social relationships. Thus, from a socioeconomic point of view, these dynamics and relationships must be considered an aspect of the organization of labour and consumption. Often intensification or specialization practices were applied to only a part of the total productive system, specifically to the part obtaining high revenue, having an ideological or ritual significance (e.g. wine as a sacred, prestige or consumption good), or were used in large-scale social or political loans as the annona system for supply grain, meat, wine and olive oil to the Roman army and the inhabitants of Rome (Pavis d'Escurac 1976; Remesal 1990; Sirks 1991), although wine apparently seems was not included in the annona until the reign of Aurelian (270 275 CE; Conison 2012).

\subsubsection{The Agency-Oriented Winegrowing Specialization Production Model}

The agency-oriented model adopted for explaining the spread of vineyard cultivation and vine-growing specialization system in the Laetanian region during the Roman period (first century BC to third century AD), is an applied version of the 
Heckscher-Ohlin-Samuelson economic model (Heckscher 1919; Ohlin 1967; Samuelson 1948, 1953-1954). This model combines the theoretical insights of the Adam Smith's principle of absolute advantage (Smith 1776), that refers to the ability of a party or territory to produce a greater or most efficient quantity of a good, product, or service than competitors, using the same amount of resources; with the 'Ricardian' principle of comparative advantage (Ricardo 1817), that considered what goods and services a party or territory should produce, and suggested what they should specialise by allocating their scarce resources to produce goods and services for which they have a comparative cost advantage. ${ }^{18}$ Thus, there are two types of cost advantage, absolute and comparative. Absolute advantage means being more productive or cost-efficient than another territory whereas comparative advantage relates to how much productive or cost efficient one is than another. All of these are in a context of a "Boserupian" pushing force of increasing population densities that triggered more intensive land use and a "Smithian" market pulling force exerted by an overseas demand for wine which induced the reallocation of land and labour towards vine-growing specialization and more capital investment in larger winemaking production centres. According to it, vine-growing specialization would have developed in the territories with more favourable factor endowments to meet the increasing demand for wine. Thus, vines tended to spread where land and labour endowments were more suitable. However, there are a set of driving forces to be considered. Some of them can be regarded as naturally given, such as agro-climatic conditions. Others depended on human agency, like migrations that changed population densities or the readiness of many landless peasants to invest their labour force in own tenancy. This could be an important factor to explain the evolution in the productive forms and in the land use changes.

This agency-oriented model of land-use change combines what environmental historians and geographers call first-nature and second-nature variables. While agro-climatic endowments are first-nature factors, the dynamic interaction between the other variables becomes a set of second-nature drivers including time-distances to the nearest seaport (network analysis), that is taken as a proxy for the marketpulling force (Badía-Miró and Tello 2014; De Soto 2010).

What eventually really matters is the combination between them. Except for the demand, all variables had to move along a specific range of values, higher than a minimum but not exceeding an upper level, so as to fit with the rest in a suitable

\footnotetext{
${ }^{18}$ The Heckscher-Ohlin-Samuelson economic model features that the best effective combination of relative factor endowments such as a favourable agroecological conditions, suitable factors of production (land, labour and capital), high technical expertise in the production processes, availability for applying technological advances and a good transportation network can determine that a comparative advantage arises. Territories have comparatives advantages in those goods for which the required factors of production are relatively abundant or suitable. This is because the profitability of goods is determined by input costs. Goods that require conditions and inputs that are locally abundant will be cheaper to produce than those goods that require inputs that are locally scarce. Technical expertise and technological advances can contribute also that these comparative advantage improves being even determinant.
} 
economic factor endowment. Local suitability to vine-growing was the outcome of a myriad of decisions taken by a lot of people interacting in a given set of challenges and opportunities which in turn they transformed. This agency-driven impulse set in motion self-reinforcing processes of vineyard planting works, and some technical advantages could be established within them. Planting vines in bush/head training system using the alveus/goblet technique without trellis infrastructure combined with the spur pruning system supposes an important technical advantage which favours both grape's productivity and harvesting efficiency (Martín i Oliveras 2015b, Figs. 16 and 17). ${ }^{19}$ In this sense, Columella (De Arboribus IV, 1-2) indicates that these efficient planting and pruning systems were already used by Carthaginians and were adopted in Hispania by native peasants and Italic colonists. André Tchernia hypothetically proposes that during the Roman period the Laetanian vineyards planted and pruned with these techniques were maintained at a height of between one Roman foot and a half $(44.4 \mathrm{~cm})$ and three Roman feet $(88.8 \mathrm{~cm})$. This fact facilitates the recollection and increased the labour productivity during the harvesting, improving its performance and reducing the production costs greatly. According to the same author, this fact, combined with strong investments in processing and storage facilities and in applying technology (tools and machinery), would explain in large part the great production capacity and the strong competitiveness of the Laetanian wines (Tchernia 1986; Martín i Oliveras 2015b).

This winegrowing specialization stops when one or several key variables exceed or diminish certain threshold values, for example, reaching population densities higher than the ones capable to be sustained by a still mainly agrarian economy, exhausting the marginal lands available for planting vineyards or dropping the external demand of wine and derivatives due the irruption of more competitive producers. The result is a dilemma. Or local economies have to start a structural change for returning to an autarchic self-sufficient system in resilience, in which demographic surpluses have to emigrate towards other places; or either they have to expand towards new economic activities. It should be noted that this agency-oriented model was previously applied by economic historians in a cross-sectional analysis in the same territory in a similar context of wine-growing specialization in the midnineteenth century, basing on the theoretical comparative advantages, factor endowment and the impact of trade openness to international markets (Tello et al. 2008; Tello and Badía-Miró 2011; Badía-Miró and Tello 2013, 2014) (Fig. 8.6).

\footnotetext{
${ }^{19}$ The head-trained and spur-pruned training system was one the most ancient vines driving techniques employed. Traditionally it was used in the coastal vineyards as well as in the foothills and interior valleys because it was inexpensive and very easy to manage because it did not need trellis infrastructure. An additional advantage to this system was that it could be cross-cultivated for weed control, a very important water conservation tool in non-irrigated vineyards (Tchernia 1986; Togores 2003; Martín i Oliveras 2015b).
} 


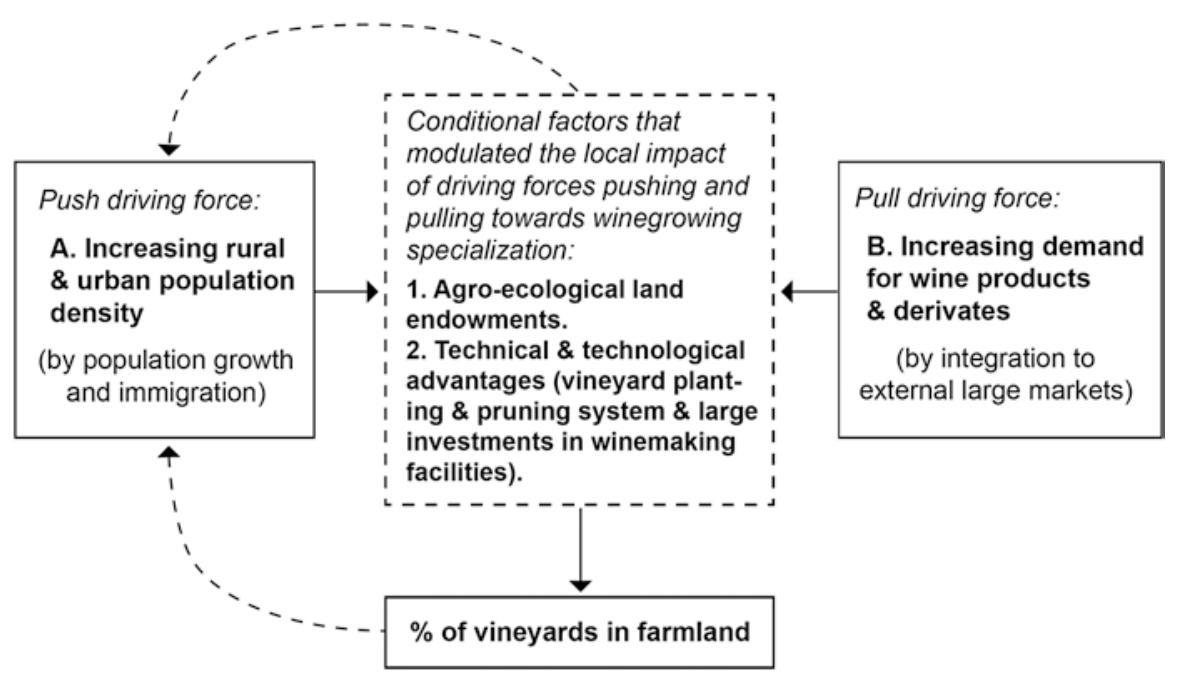

Fig. 8.6 Pushing or pulling drivers and conditioning factors of the Laetanian region's winegrowing specialization. (After Badía-Miró and Tello 2013, 22, Fig. 1)

\subsubsection{The Taxes-and-Trade Model}

Hopkins' taxes-and-trade model is a good point of departure for a further research on production and distribution economic dynamics. Insofar as it takes into account the fact that the ancient economy was in constant flux, it could be useful to analyse long-term changes and be versatile enough to accommodate local circumstances. Substantial growth in the scale of an economy is impossible without quantitative and qualitative changes in the means of production. Economic success often is matched by a growth in population. Hopkins thinks that regional trade was mainly in raw materials and foodstuffs in bulk and interregional, interprovincial and international trade were processed food products, consumer and luxury goods. He also calculates, from a macroeconomic point of view, that the Roman state needed an amount of capital about 825 million sesterces every year in the first century AD. This money was raised mainly in the form of direct and indirect taxes, and these represented $10 \%$ of the value of all economic activities in the Early Roman Empire, and they do not seem to have increased over time (Hopkins 1978; Duncan-Jones 1990; Kehoe 2013).

The "Roman villa" system, considered as an agricultural economic phenomenon with a tendency to intensification and specialization in the production and commercialization of larger cash-crop surpluses, reflects a profit mentality that exploited the accessibility to a larger distributive markets resulting in the lowering of production and transportation costs combined with the development of empire-wide political and economic institutions in which taxation plays a central role. This taxation 
affects the vine-growing and winemaking production and trade and all the stages of the productive function such as land tenure, yields, sales, revenues and so on. The internal relationships and the tensions generated by the competition for the control of the wealth and the resources by the state, civic communities and private individuals will be the key issue to understand its evolution and the changes over the time. The fact is that there was extensive Roman commerce and trade accompanied by a highly sophisticated law body to regulate it. The provinces were to carry on the heavy weight of administering the Empire. Roman state imposed a considerable number of indirect taxes, in particular customs and some taxes on trade-portoria. There were also crop taxes of 1/10 - decima vectigalis - for grain (Cic. Verr. IV-103: "agros populo Romano ex parte decima... vectigalis fuisse"); 1/5 - quinta vectigalis - for wine and olive oil; sales taxes of 1/100 - centesima rerum venalium; property tax; emergency tax; and so on, but the burden of taxation was distributed unevenly across the economy. Other issues related to land tenancy levied the crop yields and the incomes as leases and the share-cropping practices where the yield was proportionally split between landowner and tenant. These rents could oscillate around $50 \%$ of the yields, depending on the region and the product produced (Van Minnen 1998).

\subsection{Discussion and Conclusion}

There is a relationship between the processes of agrarian intensification and specialization, which are evident in the field of viticulture, and the structure and dynamics of settlement and population. These processes seem to promote the occupation of new spaces in specific territories on a regional scale. Ancient Laetania's viticulture seems to provide a good case study research.

The application of economic theory concepts could be an important tool to calculate production costs on the study of different systems of production, packing, shipment and distribution of wine. The evolution of supply and demand is determined by changes in consumption and in markets. Thus, a change of commercial orientation necessarily implies changes in the production system as well as in the system of transport and distribution of the product.

Demographic studies can also help us to calculate the amount of population, its distribution and its fluctuations over the time, trying to identify the causes of increases or decreases as regards the quantification of self-consumption needs, available workforce and hand labour division.

The extension of new productive forms requires a minimal amount of labour, necessary for the functioning of the agricultural and artisanal productive function with a complex technology and the extension of the crops. In turn, this economy can boost population growth and generate processes of increasing socio-economic inequality and the promotion of some social groups as a result of an uneven distribution of incomes and wealth generated. Part of this population growth can be evidenced by the intensification and unequal density of rural habitat and urban 
population growth, though it is hardly perceptible through the data provided by archaeological record.

The unequal extent of new economic forms of production along with other factors, not only the administrative ones, can help us to understand the different evolution of some cities and secondary settlements, in particular their function with respect to a territory and its demography, and to deepen into the global analysis of the urbanization process of the region.

Therefore, regional variability is one of the key points in understanding the changing patterns of rural settlement of any ancient historical period. Intra-regional and extra-regional economic networks seem to have been an important catalyst of specific interaction between agroecosystem and population in the ancient Laetanian region as regards the evolution of settlement patterns (urban and rural), land use, tenure, ownership management and labour division as well.

The level of dependence of the rural population of a given area in the regional market, respect the local urban centres and their subsequent screening in foreign markets, in our case study Western Europe and the Italian peninsula and Rome itself, are matters that respond to a series of socio-economic patterns and behaviours which are likely to be studied and modelled economical \& econometrically.

The wide utilization of mathematics, statistics and linear programming models allows us to analyse, interpret and make predictions, regressions and reconstructions about the evolution of an ancient economic system, in relation with potential calculation of crop yields, the consumption level, the productive surplus susceptible of being traded in external markets and the study of several variables as the sales prices, the market reactions, the production trade and transportation costs, the business tendency and the consequences of economic policies in the socio-political affairs.

Acknowledgement Special thanks to Dr. Philip Verhagen for accepting our contribution in the "Finding the Limits of the Limes Project. Final Conference" held at Vrije Universiteit Amsterdam in January 2017, and also for his confidence in commissioning us one of the chapters of this book. Many thanks also to the two peer-reviewers whose invaluable suggestions have contributed to improving the quality of this chapter. All errors of course remain on our own.

This research was funded through the projects "EPNet Project-Economic and Political Networks" (ERC-2013-ADG 340828), "Relaciones interprovinciales en el Imperio Romano. Producción y comercio de alimentos hispanos (provincias Baeticae y Tarraconensis)"(MINECO, HAR2017-85635-P) and AGAUR (2017SGR512).

\section{References}

Alcubierre D, Hinojo E, Rigo A (2015) Primers resultats de la intervenció a la vil-la romana del Pont del Treball a Barcelona. In: Tribuna d'Arqueologia 2012-2013. Departament de Cultura, Generalitat de Catalunya, Barcelona, pp 372-398

Alcubierre D, Ardiaca J, Artigues PL, Llobet S (in press) Resultats preliminars de la nova intervenció arqueològica a la vil·la romana del Pont del Treball a Barcelona. In: Tribuna d'Arqueologia 2013-2014. Departament de Cultura, Generalitat de Catalunya, Barcelona 
Amouretti M-C (1986) Le pain et l'huile dans la Grèce antique: de l'araire au moulin. Les Belles Lettres, Paris

Amouretti M-C, Brun J-P (1993) Les Rendements. In: Amouretti M-C, Brun J-P (eds) La production du vin et de l'huile en MéditerranéeÉcole Française d'Athènes, Athens/Paris, pp 551-562

Badía-Miró M, Tello E (2013) An agency-oriented model to explain vine-growing specialization in the province of Barcelona (Catalonia, Spain) in the mid-nineteenth century. In: Documents de Treball de la Facultat d'Economia i Empresa. Col-lecció d'Economia E13/290. Universitat de Barcelona, Barcelona, pp 1-31

Badía-Miró M, Tello E (2014) Vine-growing in Catalonia: the main agricultural change underlying the earliest industrialization in Mediterranean Europe (1720-1939). Eur Rev Econ Hist 18(2):203-226

Boserup E (1965) The conditions of agricultural growth. George Allen and Urwin, London

Bowman A, Wilson A (eds) (2013) The Roman agricultural economy: organization, investment and production. Oxford University Press, Oxford

Brun J-P (2004) Archéologie du vin et de l'huile. De la préhistoire à l'époque hellénistique, Errance, Paris

Burch J, Jiménez F, Nolla JM, Palahí L (2005) El fundus de Turissa entre el segle I aC i l'I dC. Arqueología de dos establiments rurals. Mas Carbotí i Ses Alzines, Girona

Carandini A (1980) Il vigneto e la Villa del fondo di Settefinestre nel Cosano: un caso di produzione agricola per il mercato transmarino. In: D'Arms JH, Kopff EC (eds) The Seaborne commerce of Ancient Rome. American Academy in Rome, Rome, pp 1-10

Carandini A (1983) Columella's vineyard and the rationality of the Roman economy. Opus 2:177-204

Carandini A (1989a) L'economia italica fra tarda Repubblica e medio impero considerata dal punto de vista di una merce: il vino. In: Amphores romaines et histoire économique. Dix ans de recherches. Actes du colloque de Sienne (22-24 mai 1986). École Française de Rome, Rome, pp 505-521

Carandini A (1989b) La villa romana e la piantagione schiavistica, In: Gabba A, Schiavone E (eds) Storia di Roma, vol 4, Caratteri e morfologie. Einaudi, Turín, pp 101-200

Carreras C (1996) A new perspective for the demographic study of Roman Spain. Revista da Historia da Arte e Arqueologia 2:59-82

Carreras C (2014) Nuevas tendencias y datos sobre la demografía romana en la Península Ibérica. Boletín del Seminario de Estudios de Arqueología LXXX:53-82

Conison A (2012) The organization of Rome's wine trade. University of Michigan, Ann Arbor

De Sena EC (2005) An assessment of wine and oil production in Rome's hinterland: ceramic, literary, art historical and modern evidence. In: Santillo Fritzell B, Klynne A (eds) Roman villas around the Urbs : interaction with landscape and environment : proceedings of a conference at the Swedish Institute in Rome, September 17-18, 2004. The Swedish Institute in Rome, Rome, pp 1-15

De Soto P (2010) Anàlisi de la xarxa de comunicacions i del transport a la Catalunya romana: estudis de distribució i mobilitat. Universitat Autònoma de Barcelona, Barcelona

Debolini M, Marraccini E, Dubeuf J-P, Geijzendorffer I, Simon-Rojo M, Targetti S, Napoleone C (2016) A Meta-analysis of land and farming system dynamics in Mediterranean basin. Paper presented at Agromed International Conference. December 1-2, 2016, Avignon

Dewar RE (1984) Environmental productivity, population regulation and carrying capacity. Am Anthropol 86:601-614. https://doi.org/10.1525/aa.1984.86.3.02a00040

Duncan-Jones R (1974) The economy of the Roman empire. Cambridge University Press, Cambridge

Duncan-Jones R (1990) Structure \& scale in the Roman economy. Cambridge University Press, Cambridge

Dyson SL (2003) The Roman countryside. Duckworth, London

El Vi a l'Antiguitat: Economia, Producció i Comerç al Mediterrani Occidental (1987) Actes I Colloqui d'arqueologia romana. Museu de Badalona, Badalona 
El Vi a l'Antiguitat: Economia, Producció i Comerç al Mediterrani Occidental (1999) II Col-loqui Internacional d'Arqueologia Romana, actes (Barcelona 6-9 de maig de 1998). Museu de Badalona, Badalona

Fentress E (2009) Peopling the countryside: Roman demography in the Albegna Valley and Jerba. In: Bowman A, Wilson AI (eds) Quantifying the Roman economy: methods and problems. Oxford UniversityPress, Oxford, pp 127-162

Garnsey P (1979) Where did Italian peasants live? Proc Camb Philol Soc 25:1-25

Garnsey P (1983) Grain for Rome. In: Garnsey P, Hopkins K, Whittaker CR (eds) Trade in the ancient economy, Chatto \& Windus, London, pp 118-130

Gliessman SR, Engles E, Krieger R (2006) Agroecology: ecological processes in sustainable agriculture, 2nd edn. CRC Press, Boca Ratón

Hanson JW, Ormant SG, Lobo J (2017) Urbanism and the division of labour in the Roman Empire. J R Soc Interface 14:20170367. https://doi.org/10.1098/rsif.2017.0367

Heckscher E (1919) The effect of foreign trade on the distribution of income. Ekonomisk Tidskrift 21:497-512

Hopkins K (1978) Economic growth and towns in classical antiquity. In: Abrams P, Wrigley EA (eds) Towns in societies. Cambridge University Press, Cambridge, pp 35-79

Jones DW (2014) Economic theory and the ancient Mediterranean. Wiley Blackwell, Malden (MA)

Johnston DE (2004) Roman villas, 5th edn. Shire Publications, Buckinghamshire

Kehoe DP (1997) Investment, profit, and tenancy: the jurists and the Roman agrarian economy. The University of Michigan Press, Ann Arbor

Kehoe DP (2013) The state and production in the Roman agrarian economy. In: Bowman A, Wilson A (eds) The Roman agricultural economy: organization, investment and production. Oxford University Press, Oxford, pp 33-53

Kloppenborg JS (2010) Reading ancient viticulture. In: The tenants in the vineyard. Ideology, economics and agrarian conflict. Mohr-Siebeck, Tübingen

Launaro A (2011) Peasants and slaves: the rural population of Roman Italy (200 BC to AD 100). Cambridge University Press, Cambridge

Lo Cascio E (1994) The size of the Roman population: Beloch and the meaning of the Augustan census figures. J Roman Stud 83:24-40

Lo Cascio E (1999) The population of Roman Italy in town and country. In: Bintliff J, Sbonias K (eds) Reconstructing past population trends in Mediterranean Europe (3000 BC-AD 1800). Oxbow Books, Oxford, pp 161-172

López Mullor A, Martín i Menéndez A (2008) Las ánforas de la Tarraconense. In: Bernal D, Ribera A (eds) Cerámicas hipanorromanas. Un estado de la cuestión. Universidad de Cádiz, Cádiz, pp 689-724

Malthus TR (1798) An essay on the principle of population, as it affects the future improvement of society with remarks on the speculations of Mr. Godwin, M. Condorcet, and Other Writers. J. Johnston, London. Available at http://oll.libertyfund.org/titles/malthus-an-essay-on-the-principle-of-population-1798-1st-ed. Accessed on 30 July 2018

Martín i Oliveras A (2009) Parc Arqueològic Cella Vinaria (Teià-Maresme-Barcelona) Descobrint el celler romà de Vallmora. In: Prevosti M, Martín i Oliveras A (eds) El Vi Tarraconense i Laietà. Ahir i Avui. Actes del Simposi. Institut Català d'Arqueologia Clàssica, Tarragona, pp 193-213

Martín i Oliveras A (2011-2012) Arqueología del vino en época romana: El Proyecto Cella Vinaria y el complejo vitivinícola de Vallmora (Teià - Maresme - Barcelona). Nuevas aportaciones a la investigación. Anales de Prehistória y Arqueologia 27-28:101-127. Available at https:// digitum.um.es/xmlui/handle/10201/46034. Accessed on 30 July 2018

Martín i Oliveras A (2012) Anàlisi tecnofuncional d'estructures productives i vitivinícoles d'època romana. Identificació i localització a Catalunya de fosses de maniobra de premses de biga amb contrapès tipus arca lapidum. Pyrenae 43(2):59-98

Martín i Oliveras A (2015a) Arqueología del Vino en Época Romana: Teoría económica, lógica productiva y comercial aplicada al envasado, la expedición, el transporte y la distribución de 
ánforas vinarias del nordeste peninsular (s. I a.C.-I d.C.). In: Martínez Ferreras V (ed) La difusión Comercial de las Ánforas Vinarias de Hispania Citerior Tarraconensis (s.I aC-I dC). Archaeopress, Oxford, pp 19-38

Martín i Oliveras A (2015b) Arqueologia del vi a l'època romana. Del cultiu al consum. Marc teòric i epistemològic, Premi d'Arqueologia Memorial Josep Barberà i Farràs (12a edició). Societat Catalana d'Arqueologia, Barcelona

Martín i Oliveras A, Bayés F (2009) Cella Vinaria de Vallmora (Teià-Maresme-Barcelona). Estudi per la reconstrucció de dues premses romanes. In: Prevosti M, Martín i Oliveras A (eds) El Vi Tarraconense i Laietà. Ahir i Avui. Actes del Simposi. Institut Català d'Arqueologia Clàssica, Tarragona, pp 215-248

Martín i Oliveras A, Martín-Arroyo DJ, Revilla V (2017) The wine economy in Roman Hispania. Archaeological data and modellization. In: Remesal J (ed) Economía Romana Nuevas perspectivas/the Roman economy new perspectives. Universitat de Barcelona, Barcelona, pp 189-236

Martín i Oliveras A, Revilla V, Carreras C, Remesal J, Van Limbergen D (forthcoming) Viticulture and demography in Laetanian Region (Hispania Citerior Tarraconensis) from 1sy century BC to 3rd century AD. Oxbow books, Oxford

Martín-Arroyo DJ (2016) Modelización de la ratio riparia/vinea: El emparrado romano entre Hasta Regia y Gades. In: Lagóstena LG (ed) Lacus autem idem et stagnus, ubi inmensa aqua convenit. Universidad de Cádiz, Cádiz, pp 105-124

Maza DF, González AJ (1992) Tratado de Economía Moderna, Ed. Panapo, Carácas

McCormick M, Büntgen U, Cane MA, Cook ER, Harper K, Huybers P, Litt T, Manning SW, Mayewski PA, More AFM, Nicolussi K, Tegel W (2012) Climate change during and after the Roman empire: reconstructing the past from scientific and historical evidence. J Interdiscip Hist 43(2):169-220. https://doi.org/10.1162/JINH_a_00379

Miret M, Sanmartí J, Santacana J (1991) From indigenous structures to the Roman world: models for the occupation of central coastal Catalonia. In: Barker G, Lloyd J (eds) Roman landscapes. Archaeological survey in the Mediterranean region. British School at Rome, London, pp 47-53

Miró J (1988) La producción de ánforas romanas en Catalunya. Un estudio sobre el comercio del vino de la Tarraconense (siglos I a.C.-I d.C.). BAR, Oxford

Morley N (1996) Metropolis and hinterland: the city of Rome and the Italian economy 200 B.C. A.D.200. Cambridge University Press, Cambridge

Morrison KD (1994) The intensification of production: archaeological approaches. J Archaeol Method Theory 1(2):111-159

Ohlin B (1967) Interregional and international trade. Harvard University Press, Cambridge (MA)

Olesti O (2006) Propiedad de la tierra y élites locales. El ejemplo del ager Barcinonensis. In: Garrido-Hory M, Gonzales A (eds) Histoire, Espaces et Marges de l'Antiquité: Hommages à Monique Clavel-Lévêque. Université de Franche-Comté, Besançon, pp 175-200

Olesti O (2009) Propietat i riquesa a l'ager Barcinonensis. In: Carreras C, Guitart J (eds) Barcino I. Marques i terrisseries d'àmfores al Pla de Barcelona. Institut d'Estudis Catalan, Barcelona, pp $141-158$

Olesti O, Carreras C (2012) Esclavos y libertos en la producción vinícola y alfarera en el Ager Barcinonensis: De la marginalidad al éxito económico. In: Reduzzi Merola F (ed) Dependenza ed emarginazione nel mondo antico e moderno. Atti del 33 Convegno G.I.R.E.A. Aracne, Rome, pp 309-333

Olesti O, Carreras C (2013) Le paysage social de la production vitivinicole dans l'ager Barcinonensis. Dialogues d'Histoire Ancienne 39(2):147-189

Oller J (2015) El territorio y poblamiento de la Layetania interior en época antigua (ss. IV a.C-I d.C). Universitat de Barcelona, Barcelona

Palahí L, Nolla JM (2010) Felix Turissa. La vil-la romana dels Ametllers i el seu fundus (Tossa de Mar, la Selva). Institut Català d'Arqueologia Clàssica, Tarragona

Palet JM (1997) Estudi territorial del Pla de Barcelona. Estructuració i evolució del territori entre l'època ibero-romana i l'altmedieval. Segles II/I aC-IX/X dC. Universitat de Barcelona, Barcelona 
Palet JM, Fiz JL, Orengo HA (2009) Centuriació i estructuració de l'ager de la Colònia de Barcino: Anàlisi arqueomorfològica i modelació del paisatge. Quaderns d'Història i Arqueologia de la Ciutat de Barcelona 5:106-123

Palet JM, Julià R, Riera S, Orengo HA, Picornell L, Llergo Y (2012) The role of the Montjuïc promontory (Barcelona). In: Bertoncello F, Braemer F (eds) Variabilités environnementales, mutations sociales: Nature, intensités, échelles et Temporalités des changements. Éditions APDCA, Antibes, pp 341-352

Palet JM, Orengo HA, Riera S (2011) Centuriación del territorio y modelación del paisaje en los llanos litorales de Barcino y Tarraco. Una investigación interdisciplinar a través de la integración de datos arqueomorfológicos y paleoambientales. In: Dall'aglio PL, Rosada G (eds) Sistemi Centuriali e Opere di Assetto Agrario tra Età Romana e primo Medioevo. Atti del convegno borgoricco (Padova)-Lugo (Ravenna) 10-12 Settembre 2009. Fabrizio Serra, Pisa, pp 113-129

Pavis d'Escurac H (1976) La préfecture de l'annone, service administratif impérial d'Auguste à Constantin. École française de Rome, Rome

Peña Y (2010) Torcularia. La producción de vino y aceite en Hispania. Institut Català d'Arqueologia Clàssica, Tarragona

Peña Y (2011-2012) Variantes tecnológicas hispanas en los procesos de elaboración de vino y aceite en época romana. Anales de Prehistoria y Arqueologia 27-28:37-57

Perkins P (1999) Etruscan settlement, society and material cultura in central coastal Etruria. BAR, Oxford

Prevosti M (2005) L'època romana. In: Giralt E (ed) Història agrària dels Països Catalans, vol I, L'antiguitat. Universitat de Barcelona, Barcelona, pp 345-445

Prevosti M, Martín i Oliveras A (2007) El vi tarraconense i laietà. Ahir i avui. Actes del Simposi, Tarragona-Teià. Institut Català d'Arqueologia Clàssica, Tarragona

Remesal J (1990) El sistema annonario como base de la evolución económica del Imperio romano. In: Hackens T, Miró M (eds) Le commerce maritime romain en Méditerranée occidentale. Conseil d'Europe, Rixensart, pp 355-367

Revilla V (1995) Producción cerámica, viticultura y propiedad rural en Hispania Tarraconensis (siglos I a.C.-III d.C.). L'Estaquirot, Barcelona

Revilla V (1998) Modelos económicos y modelos culturales en una sociedad provincial romana: El vino en Hispania. Boletim do CPA 5/6:181-202

Revilla V (2004a) Ánforas y epigrafía anfórica en Hispania Tarraconensis. In: Remesal J (ed) Epigrafía anfórica. Universitat de Barcelona, Barcelona, pp 159-196

Revilla V (2004b) El poblamiento rural en el noreste de Hispania entre los siglos II a.C. y I d.C.: organización y dinámicas culturales y socioeconómicas. In: Moret P, Chapa T (eds) Torres, atalayas y casas fortificadas. Explotación y control del Territorio en Hispania (S. III a. de C. - S. I d. de C.). Universidad de Jaén, Jaén, pp 175-202

Revilla V (2008) La producción anfórica en el sector meridional de Cataluña: prácticas artesanales, viticultura y representaciones culturales. In: Aquilue J, López A, Pascual i Guasch R (eds) La producció $\mathrm{i}$ el comerç de les àmfores de la provincia Hispania Tarraconensis. Homenatge a Ricard Pascual i Guasch (Barcelona, 17 i 18 de novembre de 2005). Museu d'Arqueologia de Catalunya, Barcelona, pp 189-226

Revilla V (2010a) Hábitat rural y territorio en el litoral oriental de Hispania Citerior: perspectivas de análisis. In: Noguera JM (ed) El poblamiento rural romano en el sureste de Hispania 15 años después. Universidad de Murcia, Murcia, pp 20-75

Revilla V (2010b) Rural settlement in the central littoral area and the interior regions of Catalonia in the 1st and 2nd centuries BC Studies on the Rural World in the Roman Period 5:139-159. Available at https://www.documentauniversitaria.media/labarqueologia/index.php/srw/article/ view/126. Accessed on 30 July 2018

Revilla V (2011-2012) Viticultura, territorio y hábitat en el litoral nororiental de Hispania Citerior durante el Alto Imperio. Anales de Prehistoria y Arqueologia 27-28:67-83 
Revilla V (2015) Agricultura, artesanado rural y territorio en el noreste de Hispania Citerior: estructuras y dinámicas. In: Martínez V (ed) La difusión comercial de las ánforas vinarias de Hispania Citerior-Tarraconensis (siglos I a.C. -I d.C.). Archaeopress, Oxford, pp 1-17

Revilla V, González JR, Prevosti M (eds) (2008-2011) Actes del Simposi Les vil·les romanes a la Tarraconense. Implantació, evolució i transformació. Estat actual de la investigació del món rural en època romana (Lleida, 28-30 novembre 2007), 2 vols. Museu d'Arqueologia de Catalunya, Barcelona

Ricardo D (1817) On the principles of political economy and taxation. John Murray, London

Rodà I, Martín i Oliveras A, Velasco C, Pou R (2005) Personatges de Barcino i el vi Laietà. Localització d'un fundus dels Pedanii Clementes a Teià (El Maresme) a partir de la troballa d'un signaculum de plom amb inscripció (segle II dC). Quaderns d'Arqueologia i Història de la ciutat de Barcelona 1:47-57

Rubin J (1972) Expulsion from the garden (Boserup and Malthus). Peasant Studies Newsletter $135-38$

Samuelson PA (1948) International trade and the equalisation of factor prices. Econ J 58(230): 163-184

Samuelson PA (1953-1954) Prices of goods and factors in general equilibrium. Rev Econ Stud 21(1):1-209

Sánchez E (ed) (1997) El jaciment romà del Morè. Sant Pol de Mar, Maresme. Departament de Cultura, Generalitat de Catalunya, Barcelona

Scheidel W (2002) A model of demographic and economic change in Roman Egypt after the Antonine plague. J Roman Archaeol 15:97-114

Scheidel W (2004) Human mobility in Roman Italy I: the free population. J Roman Stud 94:1-26

Scheidel W (2007a) Roman population size: the logic of the debate. Stanford University, Stanford

Scheidel W (2007b) Demography. In: Scheidel W, Morris I, Saller R (eds) The Cambridge economic history of the Greco-Roman world. Cambridge University Press, Cambridge, pp 38-86. https://doi.org/10.1017/CHOL9780521780537

Scheidel W, Friesen J (2009) The size of the economy and the distribution of income in the Roman Empire. J Roman Stud 99:61-91

Sirks B (1991) Food for Rome. The legal structure of the transportation and processing of supplies for the imperial distributions in Rome and Constantinople. J.C. Gieben, Amsterdam, pp vi, 44

Smith A (1776) An inquiry into the nature and causes of the wealth of nations. Thomas Dobson, Philadelphia

Tchernia A (1986) Le vin de l'Italie romaine. École Française de Rome, Rome

Tchernia A (2013) Les dimensions de quelques vignobles Romains. In: Salviat F, Tchernia A (eds) Vins, Vignerons et Buveurs de l'Antiquité. L'Erma di Bretschneider, Rome, pp 153-166

Tchernia A, Brun JP (1999) Le Vin Romain Antique, Grenoble.

Tello E, Badía-Miró M, Cussó X, Garrabou R, Valls F (2008) Explaining vineyard specialization in the province of Barcelona (Spain) in the mid-19 century. In: Documents de Treball de la Facultat de Ciències Econòmiques i Empresarials. Col-lecció d'Economia E08/201. Universitat de Barcelona, Barcelona, pp 1-42

Tello E, Badía-Miró M (2011) Land-use profiles of agrarian income and land ownership inequality in the province of Barcelona in mid-nineteenth century. In: Documentos de Trabajo, 11-01. Sociedad Española de Historia Agraria, Girona, pp 1-30

Temin P (2014) Price behaviour in the Roman Empire. In: De Callataÿ F (ed) Quantifying the Greco-Roman economy and beyond. Edipuglia, Bari, pp 189-207

Temin P (2017) The Roman market economy. Princeton University Press, Princeton

Togores JH (2003) Tratado de Enología. 2 vols. S.A Mundi, Barcelona

Tremoleda J (2008) Les instal-lacions productives d'àmfores tarraconenses. In: Aquilue J, López $\mathrm{A}$, Pascual i Guasch R (eds) La producció i el comerç de les àmfores de la provincia Hispania Tarraconensis. Homenatge a Ricard Pascual i Guasch (Barcelona, 17 i 18 de novembre de 2005). Museu Arqueològic de Catalunya, Barcelona, pp 113-150 
Van Minnen P (1998) Agriculture and the 'Taxes-and-Trade' model in Roman Egypt. Z Papyrol Epigr 133:205-220

Vilcalpoma L (1995) Teoría de la producción y costos. Una exposición didáctica. Universidad Católica del Perú, Lima

Vogel S, Märker M, Esposito D, Seiler F (2016) The ancient rural settlement structure un the Hinterland of Pompeii inferred from spatial analysis and predictive modeling of Villae Rusticae. Geoarchaeol Int J 31:121-139

Wallace-Hadrill A (1998) The Villa as cultural symbol. In: Frazer A (ed) Roman Villa. Villa Urbana. The University Museum, University of Pennsylvania, Philadelphia, pp 43-54

Witcher RE (2005) The extended metropolis - city, suburbium and population. J Roman Archaeol $18: 120-138$

Witcher RE (2008) Regional field survey and the demography of Roman Italy. In: De Ligt L, Northwood S (eds) People, land and politics. Demographic developments and the transformation of Roman Italy, 300BC-AD14. Brill, Leiden, pp 273-303

Witcher RE (2011) Missing persons? Models of Mediterranean regional survey and ancient populations. In: Bowman A, Wilson A (eds) Settlement, urbanization, and population, Oxford studies on the Roman economy. Oxford University Press, Oxford, pp 36-75

Open Access This chapter is licensed under the terms of the Creative Commons Attribution 4.0 International License (http://creativecommons.org/licenses/by/4.0/), which permits use, sharing, adaptation, distribution and reproduction in any medium or format, as long as you give appropriate credit to the original author(s) and the source, provide a link to the Creative Commons licence and indicate if changes were made.

The images or other third party material in this chapter are included in the chapter's Creative Commons licence, unless indicated otherwise in a credit line to the material. If material is not included in the chapter's Creative Commons licence and your intended use is not permitted by statutory regulation or exceeds the permitted use, you will need to obtain permission directly from the copyright holder. 